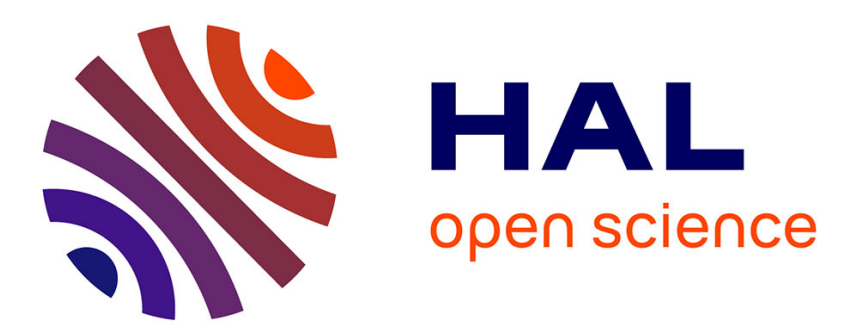

\title{
Impact of alternative cementitious material on the mechanical and transfer properties of concrete
}

Alexandre Pavoine, David Harbec, Thierry Chaussadent, Arezki Tagnit-Hamou, Loïc Divet

\section{To cite this version:}

Alexandre Pavoine, David Harbec, Thierry Chaussadent, Arezki Tagnit-Hamou, Loïc Divet. Impact of alternative cementitious material on the mechanical and transfer properties of concrete. Materials Journal, 2014, 111 (3), pp 251-261. hal-01004231

\section{HAL Id: hal-01004231 \\ https://hal.science/hal-01004231}

Submitted on 11 Jun 2014

HAL is a multi-disciplinary open access archive for the deposit and dissemination of scientific research documents, whether they are published or not. The documents may come from teaching and research institutions in France or abroad, or from public or private research centers.
L'archive ouverte pluridisciplinaire $\mathbf{H A L}$, est destinée au dépôt et à la diffusion de documents scientifiques de niveau recherche, publiés ou non, émanant des établissements d'enseignement et de recherche français ou étrangers, des laboratoires publics ou privés. 
4 Alexandre Pavoine, David Harbec, Thierry Chaussadent, Arezki Tagnit-Hamou and Loïc

5 Divet

\section{Biography:}

7 Alexandre Pavoine is Head of the Eco-material laboratory in the Technical Research Center 8 of the region of Ile-de-France (France). He received his $\mathrm{PhD}$ in materials sciences from the 9 University of Paris. The subject of his $\mathrm{PhD}$ thesis was the risk of development of Delayed 10 Ettringite Formation in concretes. His research interests include durability of concrete and the 11 development of alternative materials for concrete.

\section{IMPACT OF ALTERNATIVE CEMENTITIOUS MATERIAL ON THE MECHANICAL AND TRANSFER PROPERTIES OF CONCRETE}


1 physico-chemistry and microstructure of cement and concrete, supplementary cementitious

2 materials, and sustainable development. He is member of Board Advisory Committee on

3 Sustainable Development (BAC-SD) and committee C555 - Concrete with Recycled

4 Materials.

5

6 Loic Divet is Deputy Head of Materials Department at IFSTTAR (Paris - France). He has 7 over 25 years relevant experience, involving mainly in the engineering of construction 8 materials including concrete, mortar, stone and brick-built masonry. His research interests 9 include concrete pathology and the development of alternative materials for cement and 10 concrete.

\section{ABSTRACT}

13 An experimental program was carried out to characterize the risk of corrosion in reinforced 14 concretes, designed with alternative cementitious materials (ACMs). The study focuses on 15 three alternative cementitious materials used with ordinary Portland cement: glass powder 16 (GP) obtained from mix glass, alternative fly ash (AFA) obtained from the combustion of 17 wastepaper deinking sludge and wood residues in a fluidized-bed reactor, and limestone filler 18 (LF). Concrete specimens casted with a Water-to-Binder ratio (W/B) of 0.4 and 0.55 were 19 tested in order to determine compressive strength, chloride ion penetration, chloride diffusion, 20 and porosity accessible to water. Reinforced concretes were also submitted to accelerated 21 corrosion tests. The use of GP in replacement of cement yielded to a good resistance to 22 chloride ion penetration. In this case, low level of chloride ion penetration is maintained 23 despite the increase of W/B. Hence, measurements of chloride ion penetration do not 24 correlate with compressive strength values. The AFA slightly increases the chloride ion 
1 penetration, while the use of limestone filler has no significant impact. The chloride ion

2 penetration tests show a good relation with the accelerated corrosion tests.

4 Keywords: alternative cementitious materials, glass powder, alternative fly ash, limestone

5 filler, corrosion, chloride, concrete durability, concrete transfer properties.

6

8 Damages caused by the corrosion of steel are the main cause of premature deterioration of 9 reinforced concrete structures. In the United States, the annual cost of repair in 2002 was

\section{INTRODUCTION} evaluated to 271 million dollars ${ }^{1}$. The risk of corrosion of steel is mainly associated with either the penetration of chloride ions and/or a decrease of the $\mathrm{pH}$ induced by carbonation of the binder. The use of supplementary or alternative cementitious materials (ACMs) to replace Ordinary Portland Cement (OPC) is often required to achieve low chloride ion penetration and durable concretes. The impact of fly ash (FA), silica fume (SF) and ground granulated blast furnace slag (GGBFS) in a binary or a ternary system with OPC has been extensively studied $^{2-11}$. Pozzolanic materials are known to react slowly with calcium hydroxide, resulting from OPC hydration or already present within the added materials. Finely divided Calcium Silicate Hydrates (C-S-H) with lower $\mathrm{CaO} / \mathrm{SiO}_{2}$ ratio $(\mathrm{C} / \mathrm{S})$ are formed and fill the fine porosity $^{12}$. Limestone used in blended cements also has a chemical effect that contributes to the acceleration of calcium silicate hydration by the formation of carboaluminate phases ${ }^{13-14}$. Combined with the chemical effect, fine particles added to cement, especially limestone filler, can also provide nucleation sites to form first hydrates and thus accelerate the hydration ${ }^{15-16}$. These additional gels contribute to a densification of the microstructure and increase the pore network tortuosity ${ }^{2}$ and mechanical properties. Pozzolanic materials reduce the chloride ion penetration by modifications of the cement paste microstructure and the nature of C-S-H 
1 formed. The impact of limestone filler on concrete resistance towards chloride penetration is

2 complex. Additional negative effects may be attributed to the diluting effect of clinker, the

3 presence of a porous and connected paste-aggregate transition zone, the higher level of $\mathrm{OH}^{-}$

4 in the porous solution ${ }^{17}$, and the decrease of the ability of chloride binding into

5 carboaluminate phases ${ }^{18}$. Nevertheless, the use of limestone blended Portland cement can

6 improve the durability compare to $\mathrm{OPC}^{14}$.

7 ACMs are also developed to offer new opportunities to decrease the environmental impact of

8 concrete and contribute to the valorization of industrial by-products. This paper relates on

9 results obtained on casted concretes with a glass powder (GP) obtained by finely crushing

10 mix glass bottles, an alternative fly ash (AFA) coming from the combustion of wastepaper

11 de-inking sludge and wood residues in a fluidized bed for the co-generation of electricity, and

12 a limestone filler (LF) as a limestone blended cement. The properties of these concretes are

13 compared to those of OPC concretes.

14 Finely ground GP has a pozzolanic activity ${ }^{19-21}$. In terms of reactivity and impact on the 15 concrete durability, the properties of GP are often compared to those of class F fly ash ${ }^{22}$. Its

16 high fineness removes all risks of swelling reaction by alkali-silica reaction in concretes

17 when mixed with reactive aggregates ${ }^{23}$. AFA can have hydraulic activity, due to the presence

18 of free lime, and pozzolanic activity, due to the presence of aluminosilicate materials that can

19 react with calcium hydroxide ${ }^{24}$. If $\mathrm{ACMs}$ can contribute to a densification of the binder

20 matrix, the cement dilution and/or pozzolanic activity can reduce the resistance to

21 carbonation. As a consequence of these contrary effects, the impact of ACMs on concrete

22 durability is complex ${ }^{6,9,25}$. The specific impact of the studied ACMs on concrete durability

23 must be evaluated to promote these new materials for appropriate environmental conditions

24 for concrete structures. 
2 The mechanical properties of concretes made with ACMs are often well characterized but the 3 risk of steel corrosion is generally not deeply studied. The work carried out in this

4 investigation describes an accelerated corrosion test that allows characterizing both the

5 periods of initiation and propagation of steel corrosion in concrete. Meanwhile, it correlates

6 the impact of three ACMs to the chloride ion penetration and the risk of corrosion of

7 reinforced concretes. Also, this research illustrates the independence between concrete 8 mechanical properties and durability.

\section{EXPERIMENTAL PROCEDURE}

10 The experimental design includes eight concrete mixes. The latters consist of four different 11 binders (OPC as control, OPC substituted with $20 \%$ of GP, OPC substituted with $20 \%$ of 12 AFA, and a $10 \%$ limestone filler blended OPC (LF). The rate of $20 \%$ for the substitution of 13 OPC by GP and AFA corresponds to an optimal dosage obtained in previous works based on 14 the monitoring of mechanical properties and permeability with curing time ${ }^{26}$. The LF cement 15 is a common commercial cement that is used in this study in order to compare its properties with the other additions (AFA and GP) and OPC. Each binder is mixed using two water-to-

17 binder ratios (W/B: 0.4 and 0.55 ). For each batch, specimens were cured in a $100 \%$ relative 18 humidity room for a time depending of each specific test procedure. Concrete specimens are 19 tested for compressive strength, chloride ion penetration ${ }^{27}$ and porosity accessible to water ${ }^{28}$.

20 An accelerated corrosion test has been implemented and conducted to evaluate the behavior 21 of reinforced concretes in a rich chloride environment.

\section{$22 \quad$ Materials}

23 The physical properties and chemical analysis of GP, AFA, LF and OPC are shown in Table 241 and their particle size distribution, in Fig. 1. X-ray diffraction analysis for GP and AFA 25 have shown that GP is a totally amorphous product while AFA is composed of calcium oxide 
$1(\mathrm{CaO})$, calcium carbonate $\left(\mathrm{CaCO}_{3}\right)$, anhydrite $\left(\mathrm{CaSO}_{4}\right)$ and gehlenite $\left(\mathrm{Ca}_{2} \mathrm{Al}_{2} \mathrm{SiO}_{7}\right)$ as main

2 crystalline phases.

3 Trial using the modified Chapelle test ${ }^{29}$ confirmed that GP has a pozzolanic activity. The

4 pozzolanicity of GP was also verified by monitoring in cement pastes the decrease of the

5 portlandite peak using X-ray diffraction ${ }^{30}$. The capacity of consumption of calcium hydroxide

6 by $\mathrm{GP}$ is estimated to 418 grains $\mathrm{Ca}(\mathrm{OH})_{2} / \mathrm{oz}\left(955 \mathrm{mgCa}(\mathrm{OH})_{2} / \mathrm{g}\right)$. AFA has both a

7 pozzolanic activity and hydraulic activity. Determined by the modified Chapelle test ${ }^{29}$, AFA

8 is able to react with 36 grains $\mathrm{Ca}(\mathrm{OH})_{2} / \mathrm{oz}\left(82 \mathrm{mg} \mathrm{Ca}(\mathrm{OH})_{2} / \mathrm{g}\right)$. Taking into account of the

$99.2 \%$ of free lime initially present in AFA, the capacity of consumption of $\mathrm{Ca}(\mathrm{OH})_{2}$ by $\mathrm{AFA}$

10 is estimated to around 89 grains $\mathrm{Ca}(\mathrm{OH})_{2} / \mathrm{oz}\left(204 \mathrm{mg}\left(\mathrm{Ca}(\mathrm{OH})_{2}\right) / \mathrm{g}\right)$.

11 One siliceous sand and two crushed coarse limestone aggregates were used for concrete

12 mixes which are summarized in Table 2. An air-entraining admixture (in a range of 0.46 to

$130.89 \mathrm{oz} / \mathrm{lb}$ of binder (29.0 to $52.6 \mathrm{ml} / 100 \mathrm{~kg}$ of binder)) and a superplasticizer (in a range of

140.0 to $0.3 \mathrm{oz} / \mathrm{gal}$ of concrete $\left(0.0\right.$ to $\left.2.2 \mathrm{l} / \mathrm{m}^{3}\right)$ have been used to achieve an entrained air

15 content between $6 \%$ and $8 \%$ and an initial slump between 7.2 in. and 8.8 in. (180 and 220

$16 \mathrm{~mm}$ ). This air content range is normally indicated in Canadian specifications.

17 Specimens

18 Concrete cylinders of diameter $3.94 \mathrm{in} .(100 \mathrm{~mm})$ and length $7.87 \mathrm{in}$. $(200 \mathrm{~mm})$ were used to

19 investigate the compressive strength, chloride ion penetration and porosity accessible to water.

20 Accelerated corrosion test

21 The experimental setup designed for the accelerated corrosion test is illustrated in Fig. 2. It

22 consists of four concrete elements $(39.4 \mathrm{in} .(100 \mathrm{~cm})$ long, $3.94 \mathrm{in.}(100 \mathrm{~mm})$ thick and $7.87 \mathrm{in.}$

23 (200 mm) high) sealed together to form a closed container of 51.5 U.S gallons (195 liters) of

24 saline solution $(\mathrm{NaCl} 5 \%)$. Each side of the structure is built with a different reinforced

25 concrete with three series of three bars $(\varnothing 0.39 \mathrm{in.}(10 \mathrm{~mm}))$ distant of 3.94 in. $(100 \mathrm{~mm})$ and 
1 placed at 7.87, 13.8 and $19.7 \mathrm{in.}(20,35$ and $50 \mathrm{~mm})$ from the internal side in contact with the

2 saline solution. Each bar is 9.8 in. $(250 \mathrm{~mm})$ long. The extremity of the bars is coated with

3 epoxy to control the surface $\left(4.87 \mathrm{in}^{2} .31 .4 \mathrm{~cm}^{2}\right)$ of steel in contact with the concrete and

4 avoid interferences created by the extremity of concrete (air, cracks, liquid flow). A constant

5 difference of electrical potential of $5 \mathrm{~V}$ is imposed between each steel bar and a galvanized

6 steel grid placed at around 2 in. $(5 \mathrm{~cm})$ from the concrete. A resistance $(1 \Omega)$ placed in each

7 electric circuit allows monitoring the current in each bar via the measurement of voltage.

\section{ITEMS OF INVESTIGATION}

9 - Compressive strength test

10 Compressive strength tests are conducted in accordance with ASTM C39 31 on cylinders kept 11 in a $100 \%$ relative humidity room for $1,7,14,28$, and 91 days.

\section{2 - Rapid chloride ion penetration test}

13 The tests of rapid chloride ion penetration are conducted according to the procedure 14 described in ASTM C1202 27.

15 - Chloride ion penetration test

16 This test is conducted accordingly to the French association of Civil Engineering 17 recommendations $(\mathrm{AFGC})^{28}$. It was performed on three concrete cores of $1.97 \mathrm{in} .(5 \mathrm{~cm})$ 18 thickness taken from cylinders for each concrete. After 91 days curing, specimens were 19 saturated with a basic solution, $\mathrm{NaOH}(0.025 \mathrm{~mol} / \mathrm{l})+\mathrm{KOH}(0.083 \mathrm{~mol} / \mathrm{l})$, under vacuum 20 during 20 hours. Concrete cores are then placed between two cells. One cell contains a 3\%

$21 \mathrm{NaCl}$ solution (cathode side) and the other, a $0.3 \mathrm{~N} \mathrm{NaOH}$ solution (anode side). A $30 \mathrm{~V}$ 22 potential difference is applied between the two cells at $68^{\circ} \mathrm{F} \pm 1.8^{\circ} \mathrm{F}\left(20 \pm 1^{\circ} \mathrm{C}\right)$. Chloride ion 23 penetration is expressed by the electric charge in Coulombs passing through the core during 6 24 hours of testing. 
1 The migration depth $\left(\mathrm{X}_{\mathrm{d}}\right)$ is obtained by a pulverization of 0.05 molar silver nitrate $\left(\mathrm{AgNO}_{3}\right)$

2 on fresh broken samples. The non-stationary diffusion coefficient $\left(D_{\text {app }} \mathrm{m}^{2} / \mathrm{s}\right)$ is obtained

3 with:

$4 \quad D_{a p p}=\frac{\text { R.T.L }}{z \cdot F \cdot \Delta E} \cdot \frac{\left(X_{d}-\alpha \cdot \sqrt{X_{d}}\right)}{\Delta t}$

5 Where $\alpha=2 \xi \sqrt{\frac{R \cdot T \cdot L}{Z \cdot F \cdot \Delta E}}$ and $\xi=e r f^{-1}\left(1-2 \times \frac{c_{d}}{c_{0}}\right)$

$6 \mathrm{R}=$ the gas constant $\left(\mathrm{R}=8.3144 \mathrm{~J} \cdot \mathrm{mol}^{-1} \cdot \mathrm{K}^{-1}\right) ; \mathrm{T}=$ the absolute temperature $(\mathrm{K}) ; \mathrm{L}=$

7 specimen's thickness $(\mathrm{m}) ; \mathrm{z}=$ the valence ion $(\mathrm{z}=1) ; \mathrm{F}=$ the Faraday constant $(\mathrm{F}=96480$

$\left.8 \mathrm{~J} . \mathrm{V}^{-1}\right) ; \Delta \mathrm{E}=$ the potential drop between the surfaces of specimen $(\mathrm{V}) ; \Delta \mathrm{t}=$ test's duration (s);

$9 \mathrm{X}_{\mathrm{d}}=$ chloride depth, $\mathrm{c}_{0}=$ the chloride concentration of the catholyte solution (upstream

10 compartment) in mol. $\mathrm{L}^{-1}$ and $\mathrm{C}_{\mathrm{d}}=$ chloride threshold concentration detected by colorimetry in

11 mol. $\mathrm{L}^{-1}\left(\mathrm{C}_{\mathrm{d}}=0.07\right)$. For $\mathrm{C}_{0}=0.5$ mol. $\mathrm{L}^{-1}, \zeta=0.764$.

12 - Accelerated corrosion test

13 This test is conducted on concrete structures as described above. The concrete specimen are

14 demolded 48 hours after their fabrication and cured in a $100 \%$ relative humidity at $68^{\circ} \mathrm{F}$

$15\left(20^{\circ} \mathrm{C}\right)$ for 6 weeks. Electronic devices are connected during the $7^{\text {th }}$ week on the superficially

16 air dried concretes at $68^{\circ} \mathrm{F}\left(20^{\circ} \mathrm{C}\right)$. The $8^{\text {th }}$ week, the concrete structure is filled with tap water

17 to saturate the concrete and check the tightness and liquid leaks. The $9^{\text {th }}$ week, tap water is

18 replaced by a saline solution $(5 \% \mathrm{NaCl})$ and a potential difference of $5 \mathrm{~V}$ is applied between

19 the cathode (galvanized steel grid placed in saline solution) and the anode (each 36 bars

20 tested). For each steel bar, the voltage is periodically measured on a $1 \Omega$ resistor connected in

21 between the cathode and the anode. The measurements are thereafter converted into electrical

22 current data using the Ohm's law.

23 To investigate the microstructure at the end of the accelerated corrosion tests, the corrosion

24 products developed in the four concretes (OPC, GP, AFA, LF) mixed at a $\mathrm{W} / \mathrm{B}=0.55$ were 
1 observed using SEM and analyse using energy-dispersive spectroscopy (EDS). In this sense,

2 corroded concrete samples were cored around the reinforcing bars and fresh factures pieces

3 were taken from each core samples for SEM observations. The SEM acceleration voltage and

4 emission current were respectively set to $15.0 \mathrm{kV}$ and $60 \mu \mathrm{A}$. Complementary to these

5 microscopic investigations, corroded bars have been extracted from the four concretes (W/B

$6=0.55)$ in order to evaluate the loss of mass during the test.

7 - Porosity accessible to water

8 This test is conducted accordingly to the AFGC recommendations ${ }^{28}$. Three concrete cores (3

9 cm thickness) taken from cylinders are maintained under vacuum during 4 hours and then

10 saturated under vacuum by tap water during 20 hours. Saturated samples are weighed in air

$11\left(\mathrm{M}_{\text {air }}\right)$ and in water $\left(\mathrm{M}_{\text {water }}\right)$. Concrete samples are then air dried at $224^{\circ} \mathrm{F}\left(105^{\circ} \mathrm{C}\right)$ up to

12 constant mass $\left(\mathrm{M}_{\mathrm{dry}}\right)$. The accessible porosity to water $(\varepsilon)$ is obtained by:

$13 \quad \varepsilon(\%)=\frac{M_{a i r}-M_{d r y}}{M_{\text {air }}-M_{\text {water }}} * 100 \%$

\section{EXPERIMENTAL RESULTS AND DISCUSSION}

\section{Compressive strength}

17 Compressive strengths of concrete at 1, 7, 14, 28, and 91 days are shown in Fig. 3 and 4 for

$18 \mathrm{~W} / \mathrm{B}$ of 0.4 and 0.55 respectively. After one day, the control concrete (OPC) exhibits the 19 highest compressive strength. After 7 days, LF concretes attained similar compressive 20 strength as the control. As previously shown ${ }^{32}$, the compressive strength of $20 \%$ AFA 21 concretes after 7 days is higher than that of the control. Filler effect of LF accelerates the 22 hydration of concretes with a high W/B ratio, probably by offering nucleation sites in a more 23 diluted system. The high reactivity of AFA at early ages can be explained by its fineness that 24 may accelerate its hydraulic activity. GP concrete has the lowest compressive strength at 
1 early ages but the difference with the control concrete decreases with time due to the

2 pozzolanic activity of the GP. After 91 days, control and GP concretes have a similar 3 compressive strength.

4 For $\mathrm{W} / \mathrm{B}=0.4$, the dilution of Portland cement with limestone filler conducts to a significant 5 decrease of the compressive strength of $-1174.7 \mathrm{psi}(-8.1 \mathrm{MPa})$ after 91 days. No difference is 6 observed for a W/B ratio of 0.55 . The compressive strength of LF concretes after 7 days of 7 maturation is similar to that of OPC concretes. It may be explained by both: the nucleation 8 sites offered by LF and, the higher fineness of the LF binder.

\section{Chloride ion penetration}

10 The results of rapid chloride ion penetration tests results are illustrated in Fig. $5(\mathrm{~W} / \mathrm{B}=0.4)$

11 and $6(\mathrm{~W} / \mathrm{B}=0.55)$. After 28 days, the electrical indications of the tested concretes (in 12 Coulombs) to resist chloride ion penetration are similar for both W/B 0.4 and 0.55 . For W/B 13 of 0.4 , the electrical charges oscillated around the acceptable high limit by the standard 14 (4236 \pm 631 Coulombs), while, they are in the upper limit for W/B 0.55 (5619 \pm 1061 15 Coulombs). For a W/B ratio of 0.55 , the electrical charges of AFA, LF and OPC concretes 16 are comparable and never achieve the moderate domain comprised between 2000 and 4000

17 Coulombs. GP concrete exhibits the most important decrease of chloride ion penetration after 1828 days. After 91 days, the chloride ion penetration of this binder is more than the half of the 19 other tested binders. The great influence of GP on the reduction chloride ion penetration 20 reduction is accentuated with the increase of the W/B ratio. After 91 days, the GP chloride 21 ion penetration with W/B ratio of $0.55(1313 \pm 139$ Coulombs) is more than the third of the 22 other tested binders.

23 Nominal particle size is an important parameter to control the reactivity of $\mathrm{GP}^{19}$, but some 24 other factors, such as glass content may be considered. After 220 days, Shayan and $\mathrm{Xu}^{20}$ 
1 obtained a higher chloride ion penetration than what we obtained at a shorter time. Chloride

2 ion penetration can be reduced by increasing the GP proportion up to $30 \%$ of OPC content ${ }^{20}$.

3 For a W/B ratio of 0.55 , the use of AFA has an impact on the chloride ion penetration. Indeed,

4 it allows achieving the moderate domain comprised between 2000 and 4000 Coulombs. The

5 capacity of AFA to reduce the chloride ion penetration is less important than that of standard

6 FA, where a reduction of coefficient of chloride diffusion by more than 2 can be expected for

7 this grade of concrete ${ }^{5}$. Previous tests on concrete ages of 180 days and 1 year show that an 8 important decrease of the charge is expected in concrete with similar AFA ${ }^{33}$.

9 Fig. 7 plots de chloride ion penetration in coulombs versus the coefficient of apparent 10 chloride ion diffusion $\left(\mathrm{D}_{\text {app }}\right)$. According to the test used, the obtained $\mathrm{D}_{\text {app }}$ are in a range of 11 high $\left[0-3.33 \mathrm{E}-12 \mathrm{ft}^{2} / \mathrm{s}\left(0-3.09 \mathrm{E}-14 \mathrm{~m}^{2} / \mathrm{s}\right)\right]$ and very high durability [>3.33 E-12 $\mathrm{ft}^{2} / \mathrm{s}(3.09 \mathrm{E}-$ $\left.\left.1214 \mathrm{~m}^{2} / \mathrm{s}\right)\right]^{33}$ whereas the electrical charges measured are in a larger scale from low to high 13 chloride ion penetrations ${ }^{27}$. The comparison of these results reveals that from one side, 14 concretes can be separated from low to high chloride ion penetration and from the other side, 15 from high to very high durability. The tendency is that, when the chloride ion penetration 16 obtained by ASTM C $1202^{27}$ increases, $D_{\text {app }}$ also increases. This relation is not so clear for 17 concretes within the same range of durability. Within the high durability domain, the 18 electrical charge measured with ASTM standard can vary within a large scale (0-4000 19 coulombs) without influence on $\mathrm{D}_{\text {app }}$. The test of ASTM C1202 27 and the criteria proposed to 20 evaluate chloride ion penetration appear to be more selective than those of the French method 21 proposed by $\mathrm{AFGC}^{28}$.

\section{Corrosion test}

23 In Fig. 8, the evolution of current intensity in steel bars during the accelerated corrosion tests 24 are given for steel bars placed at $0.8 \mathrm{in} .(20 \mathrm{~mm})$ from the surface. This test gives interesting 25 data on the concrete behavior after the beginning of corrosion and more precisely the way it 
1 performs against the stress induced by the formation of chlorinated iron oxides. The current

2 variation with time can schematically be described in three steps:

3 1) The current intensity decreases with time. This diminution can be explained by a

4 continuous penetration of chloride in the porosity toward the polarized steels. Salts may

5 precipitate within the porosity making the concrete progressively less penetrable by the

6 chloride ion and/or a protective oxide layers may be formed on the steel bars.

7 2) The current intensity remains constant. This step is not systematically observed. It is

8 generally encountered with steels placed deeper in the concrete. At this stage, we assume that

9 chlorides have reached the steel bars and the corrosion process begins. The evolution of the

10 microstructure of the concrete and its penetration of chloride ions remains unchanged with

11 time.

12 3) The current intensity increases and an important variation within the three steels placed at

13 the same distance from the surface can be recorded. This increase may be explained by a

14 degradation of concrete, due to the formation of expansive corrosion products, and of the

15 protective oxide layers on the steel bars. It may depend of the concrete resistance towards the

16 tensile stresses generated by the formation of corrosion products. The crack spread is

17 complex and can be greatly different between the three bars placed at the same distance from

18 the surface.

19 The test on the structure made with four concretes with a W/B ratio of 0.55 was stopped after

2032 days because of large cracks causing major leaks of chloride solution.

21 The initial current measurements give information on concrete resistances. It can be clearly 22 observed that concretes with a W/B ratio of 0.55 have initial current intensity higher than 23 those measured on concretes with a W/B ratio of 0.4 . According to the chloride ion 24 penetration measurements, the lowest initial currents are measured on concretes with GP. 
1 One should also note that the initial intensity obtained for GP concretes and W/B ratio of 0.55

2 is lower than those measured on other concretes with a lower W/B ratio of 0.4 .

3 This test gives information about the resistance to chloride ion penetration by the

4 determination of the duration before the corrosion is detected. In Fig. 8 for steels placed at

50.8 in. $(20 \mathrm{~mm})$ from the surface, the corrosion seems to begin rapidly. OPC, AFA and LF

6 concretes readily start with a higher initial current than the GP concrete: $8-10 \mathrm{~mA}$ for

$7 \mathrm{~W} / \mathrm{B}=0.4$ concretes and $12-\mathrm{mA}$ for $\mathrm{W} / \mathrm{B}=0.55$ concrete. currents increase (step 3) within the

8 seven first days for $\mathrm{W} / \mathrm{B}=0.4$, and within the first three days for $\mathrm{W} / \mathrm{B}=0.55$. The concretes are

9 immediately damaged after the beginning of the corrosion test. At $\mathrm{W} / \mathrm{B}=0.4$, it exists a period

10 of time when the current remains constant (step 2) after 7 days and the cracks development

11 provoke a sudden increase of the current intensity (step 3) with large variations. In the case of

12 the LF concrete, this occurs 15-20 days after the corrosion test was initiated. In the case of

13 the OPC and AFA concrete, this occurs 35-40 days after corrosion test was initiated.

14 For GP concretes, the current slightly decreases within the first five days (step 1) for

$15 \mathrm{~W} / \mathrm{B}=0.4$ and slightly increase within the first seven days (step 3 ) for $\mathrm{W} / \mathrm{B}=0.55$. The current

16 remains constant afterwards (step 2) for both concretes. Similar observations can be drawn

17 from the monitoring of current intensity in bars placed at $1.4 \mathrm{in}$. (35 mm) from the surface of

18 the concrete.

19 Fig. 9 represents the time taken to detect corrosion at the end of step 1 for concretes with a

20 W/B ratio of 0.4 (Fig. 9a) and 0.55 (Fig. 9b). This time increases quasi-linearly with the

21 distance between the steel bars and the surface of concrete exposed to the saline solution.

22 This accelerated test of corrosion confirms the results obtained with the chloride ion

23 penetration tests. Indeed, GP concretes have high resistance to chloride ion penetration. The

24 use of this $\mathrm{ACM}$ with $\mathrm{W} / \mathrm{B}=0.55$ allows reaching similar resistance to chloride ion

25 penetration than that of the control concrete with $\mathrm{W} / \mathrm{B}=0.4$. The relative mass losses with 
1 respect to the initial bar weight are given in Table 3 for bars initially placed at $20 \mathrm{~mm}$ from

2 the surface exposed to chloride solution.

3 Shayan and $\mathrm{Xu}^{20}$ show that the use of $20 \%$ GP in substitution of OPC does not have an

4 impact on the dynamic modulus of elasticity (E). The good behavior of GP concrete is not

5 thus explained by an increase of E. As it can be seen in Table 3, the quantities of corrosion

6 products are two to three times less important for GP concrete compares to OPC, LF and

7 AFA concretes. After 32 days of testing, the better resistance of GP concretes to the

8 generation of cracks may be explained by lower quantity of corrosion products. The lower

9 quantity of corrosion products thus exercises less tensile strength on the concrete.

10 Porosity accessible to water

11 The porosity accessible to water obtained by applying the method recommended by AFGC ${ }^{28}$

12 is represented in Fig. 10. For concretes with W/B of 0.4 , porosity varies closely between 13.0

13 and 15.1. The partial substitution of cement by $10 \%$ LF or $20 \%$ ACMs does not have a

14 significant impact after 91 days curing. The increase of W/B implies an increase of the

15 accessible porosity. OPC and $10 \%$ LF concretes show comparable porosity of $16.2 \%$ and

$1616.0 \%$ respectively. Contrary to concretes with $\mathrm{W} / \mathrm{B}$ of 0.4 , the substitution of cement by

$1720 \% \mathrm{ACMs}$ in concretes with $\mathrm{W} / \mathrm{B}$ of 0.55 resulted in an increase of porosity. Very high

18 values of $20.1 \%$ and $21.1 \%$ are obtained for AFA and GP.

19 There is no relation between the porosity accessible to water and the resistance to chloride

20 ion penetration and accelerated corrosion. Specifically for concretes with GP that have a

21 pozzolanic activity, the densification of the microstructure and the increase of the tortuosity

22 do not imply a decrease of porosity accessible to water. Attention should be paid to the fact

23 that the porosity accessible to water has a low degree of significance with the real transfer

24 properties of concrete. 


\section{SEM examination of concretes after corrosion test}

2 The chloride ions $\left(\mathrm{Cl}^{-}\right)$penetration during the accelerated corrosion tests notably initiates 3 reaction between $\mathrm{Cl}^{-}$and Portlandite and weakens the protective hydroxide film on the steel

4 bars. These phenomena may also affect the microstructure and the hydration products, by 5 generating expansive corrosion products consisting of iron oxides $\left(\mathrm{Fe}_{\mathrm{x}} \mathrm{O}_{\mathrm{y}}\right)$ and oxy-chloride $6 \quad\left(\mathrm{Fe}_{\mathrm{x}} \mathrm{O}_{\mathrm{y}} \mathrm{Cl}_{\mathrm{z}}\right)$ around the steel bars ${ }^{34}$.

7 Depending on its ability to resist to chloride ions penetration, concrete will develop different 8 morphologies of corrosion products with different $\mathrm{Fe} / \mathrm{Cl}$ ratio. Thus, this ratio will decrease 9 with the increase of the chloride penetration and corrosion of the armature bars. While Fig. 1011 to 14 present the morphology of the corrosion products and their respective EDS spectrum 11 obtained in four different concretes at the same W/B (OPC 0.55, 20\% GP 0.55, 20\% AFA $120.55,10 \%$ LF 0.55 ). Table 4 summarizes the morphology type of the corrosion products 13 observed in each concrete and their respective $\mathrm{Fe} / \mathrm{Cl} \%$ atomic ratios. Empty cells means that 14 the associated corrosion product is not observed in the concrete.

15 1. OPC 0.55

16 Fig. 11 presents the morphology of the corrosion production and their respective EDS 17 spectrum observed in OPC 0.55 . This concrete globally contains two types of corrosion 18 products: a) nested flower-like and b) lamellar-like corrosion products. These products show $19 \mathrm{a} \mathrm{Fe} / \mathrm{Cl}$ ratios of 1.8 and 2.1 respectively. Petals in the flower-like products are 1 to $3 \mu \mathrm{m}$ 20 wide, while the lamellae in the second products are 20 to $40 \mu \mathrm{m}$ wide.

$2120 \%$ GP 0.55

22 Fig. 12 presents the morphology of the corrosion production and their respective EDS 23 spectrum observed in $20 \%$ GP 0.55 . This concrete mainly develops a gel-like corrosion 24 product. This product indicates a $\mathrm{Fe} / \mathrm{Cl}$ of around 12.3.

$25 \quad 3.20 \%$ AFA 0.55 
1 Fig. 13 exhibits the morphology of the corrosion production and their respective EDS

2 spectrum observed in $20 \%$ AFA 0.55 . This concrete globally contains a) gel-like, b) globular-

3 like and c) hexagonal crystal-like corrosion products. These products indicate a $\mathrm{Fe} / \mathrm{Cl}$ ratio in

4 the 1.3-2.2 range. As for 20\% GP 0.55 , the gel-like material is widely spread in the concrete

5 sample and the globular products show globules of 1 to $5 \mu \mathrm{m}$ in diameter. The hexagonal

6 crystal-like products are $\approx 10 \mu$ m wide.

4. Binary OPC-LF concrete (LF 0.55)

9 Fig. 14 exhibits the morphology of the corrosion production and their respective EDS 10 spectrum observed in $10 \%$ LF 0.55 . This concrete globally contains three different corrosion 11 products with the following morphologies: a) a gel-like and globular-like, b) nested needle12 like and c) lamellar-like corrosion products. These show a $\mathrm{Fe} / \mathrm{Cl}$ in the 1.2-8.0 range. The 13 gel-like material and the nested needle-like product are widely spread in the concrete sample 14 and the globular products shows globules of 1 to $10 \mu \mathrm{m}$ in diameter. Lamellae are 10 to 20 $15 \mu \mathrm{m}$ wide.

16 Globally, the $\mathrm{Fe} / \mathrm{Cl}$ ratios in Table 4 agree with results obtained from the chloride ion 17 penetration and the accelerated corrosion tests, meaning that these ratios decrease with the 18 increase of the current intensity measured during the first and the second tests. $20 \%$ GP 0.55 19 concrete, which shows the lowest current value during both the chloride ions penetration and 20 accelerated corrosion tests, exhibits the least amount of corrosion products of product and the 21 highest $\mathrm{Fe} / \mathrm{Cl}$ ratio values. OPC $0.55,20 \%$ AFA 0.55 and 10\% LF 0.55 concretes, which 22 show comparable results during both the chloride ions penetration and accelerated corrosion 23 tests, also indicate comparable low $\mathrm{Fe} / \mathrm{Cl}$ ratios. 
2 Besides their environmental impact, the use of ACMs brings additional mechanical and

3 durability properties to concrete. The present work illustrates that the use of these ACMs has

4 an impact on both the mechanical and transfer properties of concrete, such as the chloride ion

5 penetration and accelerated corrosion. At early ages (1 day), the dilution of OPC by ACMs

6 reduces the compressive strength. With time, concrete mixes designed with ACMs achieve

7 similar or greater compressive strengths than those attained by OPC concretes.

8 For the transfer properties, the replacement of $10 \%$ of OPC by LF or $20 \%$ of OPC by AFA

9 has no significant consequence on the resistance to chloride ion penetration. The pozzolanic

10 activity of GP decreases the chloride ion penetration of concrete. This effect is also observed

11 at high $\mathrm{W} / \mathrm{B}$.

12 The accelerated corrosion tests on reinforced concretes clearly show that concrete with $20 \%$

13 GP exhibits a good resistance to the formation of corrosion products on steel bars, while the

14 other tested concretes are rapidly damaged using the same accelerated conditions.

15 Measurements of the porosity accessible to water show no relationship with the resistance to

16 chloride ion penetration and accelerated corrosion. Contrary to the chloride ion penetration

17 and acceleration corrosion tests, porosity accessible to water does not take into account the 18 tortuosity of the microstructure.

\section{ACKNOWLEDGMENTS}

20 The authors wish to express their acknowledgments to the Funds Research on Nature and

21 Technology of Québec and the French ministry of ecology for their financial support. They

22 also express their acknowledgments to Mr. Ablam Zidol and Mrs. Eleonore Mocaer for their

23 contribution to this study. 
2 1. Koch, G.H.; Brongers, M.P.H.; Thompson, N.G.; Virmani, Y.P., and Payer J.H.,

3 "Corrosion costs and preventive strategies in the United States", Supplement to Materials

4 Performance, July 2002, 11 p.

5 2. Li, S., and Roy; D.M., "Investigation of relations between porosity, pore structure, and $\mathrm{Cl}^{-}$

6 diffusion of fly ash and blended cement pastes", Cement and Concrete Research, V. 16, 1986, $7 \quad$ pp. $749-59$.

8 3. Song, H.-W., and Saraswathy, V., "Carbonation - Comparison of results for concretes 9 containing PFA, cimentitious SLAG, or alternative aggregates”, Materials Science and 10 Technology, V. 3, I. 2, 1986, pp.986-992.

11 4. Gjorv, O.E., "Effect of condensed silica fume on steel corrosion in concrete", $A C I$ 12 Materials Journal, V. 92, I. 6, 1995, pp. 591-598.

13 5. Dhir, R.K., and Jones M.R., "Development of chloride-resisting concrete using fly ash", 14 Fuel, V. 78, 1999, pp. 137-142.

15 6. Osborne, G.J., "Durability of Portland blast-furnace slag cement concrete", Cement and 16 Concrete Composites, V. 21, I. 1, 1999, pp. 11-21.

17 7. Marcotte, T.D., "The influence of silica fume on the corrosion resistance of steel in high 18 performance concrete exposed to simulated sea water", Journal of Materials Science, V. 38, I. $19 \quad 23,2003$, pp. 4765-4776.

20 8. Thomas, M.D.A., and Matthews, J.D., "Performance of pfa concrete in a marine 21 environment, 10-year results", Cement and Concrete Composites, V 26, I. 1, 2004, pp. 5-20.

22 9. Song, H.-W., and Saraswathy, V. "Studies on the corrosion resistance of reinforced steel in 23 concrete with ground granulated blast-furnace slag - An overview", Journal of Hazardous 24 Materials, V. 138, I. 2, November 2006, pp. 226-233.

25 10. Yuan, Q.; Shi, C.; De Schutter, G.; Audenaert, K., and Deng, D., "Chloride binding of 
1 cement-based materials subjected to external chloride environment - A review",

2 Construction and Building Materials, V. 23, 2009, pp. 1-13.

3 11. Cheewaket, T.; Jaturapitakkul, C., and Chalee, W. "Long term performance of chloride

4 binding capacity in fly ash concrete in a marine environment", Construction and Building

$5 \quad$ Materials, V. 24, 2010, pp. 1352-1357.

6 12. Richardson, I.G., "The nature of C-S-H in hardened cements", Cement and Concrete

7 Research, V. 29, I. 8, 1999, pp. 1131-1147.

8 13. Kakali, G.; Tsivilis, S.; Aggeli, E., and Bati, M., "Hydration products of $\mathrm{C}_{3} \mathrm{~A}, \mathrm{C}_{3} \mathrm{~S}$ and

9 Portland cement in the presence of $\mathrm{CaCO}_{3}$ ", Cement and Concrete Research, V. 30, I. 7, $10 \quad 2000$, pp. 1073-1077.

11 14. Tsivilis, S.; Chaniotakis, E.; Kakali, G., and Batis, G., "An analysis of the properties of

12 Portland limestone cements and concrete", Cement and Concrete Composites, V. 24, I. 3-4, 13 2002, pp. 371-378.15.

14 15. Gutteridge, W.A, and Dalziel, J.A., "Filler cement: the effect of the secondary component 15 on the hydration of Portland cement: Part I. A fine non-hydraulic filler", Cement and 16 Concrete Research, V.20, I. 5, 1990, pp. 778-782.

17 16. Bentz, D.P., "Modeling the influence of limestone filler on cement hydration using 18 CEMHYD3D”, Cement and Concrete Composites, V. 28, I. 2, 2006, pp 124-129.

19 17. Ghrici, M.; Kenai, S., and Said-Mansour, M., "Mechanical properties and durability of 20 mortar and concrete containing natural pozzolana and limestone blended cements", Cement 21 and Concrete Composites, V. 29, I. 7, 2007, pp 542-549.

22 18. Ipavec, A.; Vuk, T.; Gabrovšek R., and Kaučič, V., "Chloride binding into hydrated 23 blended cements: The influence of limestone and alakalinity", Cement and Concrete 24 Research, V.48, 2013, pp 74-85.

25 19. Shi, C.; Wu, Y.; Riefler, C., and Wang, H., "Characteristics and pozzolanic reactivity of 
1 glass powders", Cement and Concrete Research, V. 35, I.5, 2005, pp. 987-993.

2 20. Shayan A., and $\mathrm{Xu}$, A., "Performance of glass powder as a pozzolanic material a field

3 trial on concrete slabs", Cement and Concrete Research, V. 36, I. 2, 2006, pp. 457-468.

4 21. Idir, R.; Cyr, M., and Tagnit-Hamou, A., "Pozzolanic properties of fine and coarse color-

5 mixed glass cullet", Cement and Concrete Composites, V.33, I. 1, 2011, pp. 19-29.

6 22. Schwarz, N.; Cam, H., and Neithalath, N., "Influence of a fine glass powder on the

7 durability characteristics of concrete and its comparison to fly ash", Cement and Concrete

8 composites, V. 30, I. 6, 2008, pp. 486-496.

9 23. Idir, R.; Cyr, M., and Tagnit-Hamou, A., "Use of fine glass as ASR inhibitor in glass 10 aggregate mortars", Construction and Building Materials, V. 24, I. 7, 2010, pp. 1309-1312.

11 24. Bai, J.; Chaipanich, A.; Kinuthia, J.M.; O'Farrell, M.; Sabir, B.B.; Wild, S., and Lewis, 12 M.H., "Compressive strength and hydration of wastepaper sludge ash-ground granulated 13 blastfurnace slag blended pastes", Cement and Concrete Research, Vol. 33, I. 8, 2003, pp. $14 \quad 1189-1202$.

15 25. Ramezanianpour, A.A., and Malhotra, V.M., "Effect of curing on the compressive 16 strength, resistance to chloride-ion penetration and porosity of concretes incorporating slag, 17 fly ash or silica fume”, Cement and Concrete Composites, V. 17, I. 2, 1995, pp. 125-133.

18 26. Zidol, A.; Pavoine, A., and Tagnit-Hamou, A., "Effect of glass powder on concrete 19 permeability", International Congress on Durability of Concrete, Trondheim, Norway, 18-21 20 June 2012.

21 27. ASTM C1202 - 97, "Standard Test Method for Electrical Indication of Concrete's Ability 22 to Resist Chloride Ion Penetration", ASTM International, West Conshohocken, PA, USA, 6 23 pages.

24 28. AFGC, “GranDuBé : Grandeurs associées à la Durabilité des Bétons”, Presses Ponts et 25 Chaussées, 2007, ISBN-10: 285978425X, 437 pages. 
1 29. AFNOR NF P18-513., "Métakaolin, addition pouzzolanique pour bétons - Définitions,

2 spécifications, critères de conformité”, Mars 2010.

3 30. Harbec, D.; Tagnit-Hamou, A., and Gitzhofer, F. "Waste glass nanoparticles as an

4 alternative supplementary cementitious material", $13^{\text {th }}$ Int. Congr. Chem. of Cement, Madrid, $5 \quad$ Spain, 3 to 8 July $2011,626$.

6 31. ASTM C39/C39M-03, "Standard Test Method for Compressive Strength of Cylindrical

7 Concrete Specimens", ASTM International, West Conshohocken, PA, USA, 5 pages.

8 32. Xie, A.; Laldji, S.; Mikanovic, N., and Tagnit-Hamou, A. "Wastepaper Sludge Ash: A

9 New Type of Supplementary Cementitious Material Used in Concrete", XIII International 10 congress on the chemistry of cement, Madrid, 3-8 July, 2011.

11 33. AFGC, "Conception des bétons pour une durée de vie donnée des ouvrages, Maîtrise de

12 la durabilité vis-à-vis de la corrosion des armatures et de l'alcali-réaction, État de l'art et 13 guide pour la mise en œuvre d'une approche performantielle et prédictive sur la base 14 d'indicateurs de durabilité", juillet 2004, 252 pages (In French).

15 34. Koleva, D.A.; Hu J.; Fraaij, A.L.A.; Stroeven, P.; Boshkov, N., and de Wit, J.H.W., 16 "Quantitative characterisation of steel/cement paste interface microstructure and corrosion 17 phenomena in mortars suffering from chloride attack", V. 48, I. 12, Corrosion science, 2006, $18 \quad$ pp. $4001-4019$. 
3 List of Tables:

4 Table 1 - Chemical and physical analysis of materials (\% by mass)

5 Table 2 - Mixture proportions of concretes

6 Table 3 Relative mass loss of bars with respect to their initial weight. Bars are extracted

7 from concretes with W/B of 0.55 after corrosion test with a duration of 32 days.

9 Table 4. Atomic $\mathrm{Fe} / \mathrm{Cl}$ ratio of corrosion products: empty cells signify that the

10 associated corrosion product is not observed in the concrete.

List of Figures:

13 Fig. 1 - Particle size distribution of materials using laser granulometry.

14 Fig. 2 - Experimental setup for accelerated corrosion test.

15 Fig. 3 - Compressive strength vs time in $\mathbf{1 0 0} \%$ relative humidity room for concrete with 16 a W/B ratio of 0.4 .

17 Fig. 4 - Compressive strength vs time in $\mathbf{1 0 0 \%}$ relative humidity room for concrete with 18 a W/B ratio of $\mathbf{0 . 5 5}$.

19 Fig. 5 - Coulomb charge of concretes with a W/B ratio of 0.4 vs curing time curing.

20 Fig. 6 - Coulomb charge of concretes with a W/B ratio of 0.55 vs curing time.

21 Fig. 7 - Comparison between chloride ion penetration obtained with ASTM C1202

22 and the coefficient of apparent chloride ions diffusion obtained with the method

23 recommended by $\mathrm{AFGC}^{28}$

24 Fig. 8 - Corrosion accelerated test. Monitoring of electrical current in steel bars placed 25 at 0.8 inch $(20 \mathrm{~mm})$ from the saline solution 
1 Fig. 9 - Time taken to detect of corrosion depending on the distance between steel bars

2 and saline solution in concrete for W/B of 0.4 (a) and W/B of 0.55 (b).

3 Fig. 10 - Porosity accessible to water (AFGC 2007 ${ }^{28}$ ) and durability (AFGC 2004 ${ }^{33}$ )

4 Figure 11 - SEM micrographs and EDS spectra of a) nested flower-like and b) lamellar-

$5 \quad$ like corrosion products observed in OPC 0.55 .

6 Figure 12 - SEM micrographs and EDS spectra of gel-like corrosion product observed

7 in GP 0.55 .

8 Figure 13 - SEM micrographs and EDS spectra of a) gel-like material and globular-like

9 and b) of hexagonal crystal-like corrosion products in AFA 0.55 .

10 Figure 14 - SEM micrographs and EDS spectra of a) gel-like and globular-like, b)

11 nested needle-like and c) lamellar-like in LF 0.55 . 
2 Table 1 Chemical and physical analysis of materials (\% by mass).

\begin{tabular}{|c|c|c|c|c|}
\hline Oxide & $\mathrm{OPC}$ & AFA & $\mathrm{LF}$ & GP \\
\hline $\mathrm{SiO}_{2}$ & 20.3 & 26.00 & 18.4 & 71.80 \\
\hline $\mathrm{Al}_{2} \mathrm{O}_{3}$ & 4.68 & 15.60 & 4.35 & 1.55 \\
\hline $\mathrm{Fe}_{2} \mathrm{O}_{3}$ & 2.78 & 2.32 & 2.50 & 0.38 \\
\hline $\mathrm{CaO}$ & 63.80 & 41.60 & 62.4 & 11.10 \\
\hline $\mathrm{MgO}$ & 1.98 & 2.23 & 1.84 & 1.23 \\
\hline $\mathrm{K}_{2} \mathrm{O}$ & 0.82 & 0.75 & 0.65 & 0.52 \\
\hline $\mathrm{Na}_{2} \mathrm{O}$ & 0.23 & 0.84 & 0.22 & 12.90 \\
\hline $\mathrm{SO}_{3}$ & 3.33 & 3.71 & 2.98 & -- \\
\hline LOI & 2.61 & 3.30 & 7.25 & 0.04 \\
\hline $\mathrm{D}_{50}, \mu \mathrm{m}$ & 25.8 & 74.5 & 15.2 & 12.3 \\
\hline Blaine, $\mathrm{ft}^{2} / \mathrm{lb}$ & 1,904 & 5,224 & 2,470 & 2,148 \\
\hline$\left(\mathrm{m}^{2} / \mathrm{kg}\right)$ & (390) & (1070) & $(506)$ & $(440)$ \\
\hline $\mathrm{BET}, \mathrm{ft}^{2} / \mathrm{lb}$ & 6,103 & 16,941 & 7,811 & 3,222 \\
\hline$\left(\mathrm{m}^{2} / \mathrm{kg}\right)$ & $(1,250)$ & $(3,470)$ & $(1,600)$ & $(660)$ \\
\hline $\begin{array}{l}\text { Pozzolanic } \\
\text { activity*, grains } \\
\mathrm{Ca}(\mathrm{OH})_{2} / \mathrm{oz} \\
\left(\mathrm{mgCa}(\mathrm{OH})_{2} / \mathrm{g}\right)\end{array}$ & -- & $\begin{array}{c}36 \\
(82)\end{array}$ & -- & $\begin{array}{c}418 \\
(955)\end{array}$ \\
\hline
\end{tabular}

4 Table 2 Mixture proportions of concretes.

\begin{tabular}{|c|c|c|c|c|c|c|c|c|c|}
\hline \multirow[t]{2}{*}{ Mix labels } & \multirow{2}{*}{$\begin{array}{l}\text { Binder } \\
(\%) \mathrm{lb} / \mathrm{lb} \\
(\mathrm{g} / \mathrm{g})\end{array}$} & \multirow[t]{2}{*}{$\mathrm{W} / \mathrm{B}$} & \multicolumn{4}{|c|}{ Composition, $\mathrm{lbs} / \mathrm{yd}^{3}\left(\mathrm{~kg} / \mathrm{m}^{3}\right)$} & \multirow[b]{2}{*}{ Water } & \multicolumn{2}{|c|}{$\begin{array}{c}\text { Fresh concrete } \\
\text { properties }\end{array}$} \\
\hline & & & Binder & $\begin{array}{c}\text { Sand } \\
(0-5 \mathrm{~mm}) \\
\left(0-1 / 4^{\prime \prime}\right)\end{array}$ & $\begin{array}{c}\text { Fine } \\
\text { aggregate } \\
(5-14 \mathrm{~mm}) \\
\left(1 / 4-1 / 2^{\prime \prime}\right)\end{array}$ & $\begin{array}{c}\text { Coarse } \\
\text { aggregate } \\
(10-20 \mathrm{~mm}) \\
(3 / 8-3 / 4 ”)\end{array}$ & & $\begin{array}{c}\text { Air } \\
\text { Entrained } \\
(\%)\end{array}$ & $\begin{array}{l}\text { Slump, } \\
\text { inches } \\
(\mathrm{mm})\end{array}$ \\
\hline OPC-0.4 & $100 \% \mathrm{OPC}$ & 0.4 & $\begin{array}{c}651 \\
(400) \\
\end{array}$ & $\begin{array}{l}1105 \\
(679)\end{array}$ & $\begin{array}{l}1394 \\
(856)\end{array}$ & $\begin{array}{c}348 \\
(214) \\
\end{array}$ & $\begin{array}{l}260.2 \\
(160)\end{array}$ & 7.4 & $\begin{array}{c}7.4 \\
(185) \\
\end{array}$ \\
\hline OPC- 0.55 & $100 \% \mathrm{OPC}$ & 0.55 & $\begin{array}{c}570 \\
(350)\end{array}$ & $\begin{array}{l}1040 \\
(639)\end{array}$ & $\begin{array}{l}1394 \\
(856)\end{array}$ & $\begin{array}{c}348 \\
(214)\end{array}$ & $\begin{array}{c}313.8 \\
(192.5)\end{array}$ & 6.6 & $\begin{array}{c}7.2 \\
(180)\end{array}$ \\
\hline GP-0.4 & \begin{tabular}{|c|}
$80 \%$ OPC \\
$20 \%$ GP
\end{tabular} & 0.4 & $\begin{array}{c}651 \\
(400)\end{array}$ & $\begin{array}{l}1079 \\
(663) \\
\end{array}$ & $\begin{array}{l}1394 \\
(856) \\
\end{array}$ & $\begin{array}{c}348 \\
(214) \\
\end{array}$ & $\begin{array}{l}260.2 \\
(160)\end{array}$ & 6.6 & $\begin{array}{c}8.8 \\
(220) \\
\end{array}$ \\
\hline GP-0.55 & $\begin{array}{l}80 \% \text { OPC } \\
20 \% \text { GP }\end{array}$ & 0.55 & $\begin{array}{c}570 \\
(350)\end{array}$ & $\begin{array}{l}1018 \\
(625)\end{array}$ & $\begin{array}{l}1394 \\
(856)\end{array}$ & $\begin{array}{c}348 \\
(214)\end{array}$ & $\begin{array}{c}313.8 \\
(192.5)\end{array}$ & 6.4 & $\begin{array}{c}7.2 \\
(180)\end{array}$ \\
\hline AFA-0.4 & $\begin{array}{l}80 \% \text { OPC } \\
20 \% \text { AFA }\end{array}$ & 0.4 & $\begin{array}{c}651 \\
(400)\end{array}$ & $\begin{array}{l}1099 \\
(675)\end{array}$ & $\begin{array}{l}1394 \\
(856)\end{array}$ & $\begin{array}{c}348 \\
(214)\end{array}$ & $\begin{array}{l}260.2 \\
(160)\end{array}$ & 5.0 & $\begin{array}{c}7.2 \\
(180)\end{array}$ \\
\hline AFA- 0.55 & $\begin{array}{l}80 \% \text { OPC } \\
20 \% \text { AFA }\end{array}$ & 0.55 & $\begin{array}{c}570 \\
(350)\end{array}$ & $\begin{array}{l}1032 \\
(634)\end{array}$ & $\begin{array}{l}1394 \\
(856)\end{array}$ & $\begin{array}{c}348 \\
(214)\end{array}$ & $\begin{array}{c}313.8 \\
(192.5)\end{array}$ & 6.6 & $\begin{array}{c}7.2 \\
(180)\end{array}$ \\
\hline LF-0.4 & $10 \% \mathrm{LF}$ & 0.4 & $\begin{array}{c}651 \\
(400)\end{array}$ & $\begin{array}{l}1104 \\
(678)\end{array}$ & $\begin{array}{l}1394 \\
(856)\end{array}$ & $\begin{array}{c}348 \\
(214)\end{array}$ & $\begin{array}{l}260.2 \\
(160)\end{array}$ & 7.2 & $\begin{array}{c}8.2 \\
(205)\end{array}$ \\
\hline LF-0.55 & $10 \% \mathrm{LF}$ & 0.55 & $\begin{array}{c}570 \\
(350)\end{array}$ & $\begin{array}{l}1039 \\
(638)\end{array}$ & $\begin{array}{l}1394 \\
(856)\end{array}$ & $\begin{array}{c}348 \\
(214)\end{array}$ & $\begin{array}{c}313.8 \\
(192.5)\end{array}$ & 6.2 & $\begin{array}{c}7.4 \\
(185)\end{array}$ \\
\hline
\end{tabular}

5

6 Table 3. Relative mass loss of bars with respect to their initial weight. Bars are extracted from concretes

7 with W/B of 0.55 after corrosion test with a duration of 32 days.

\begin{tabular}{|l|c|c|c|c|}
\cline { 2 - 5 } \multicolumn{1}{c|}{} & \multicolumn{4}{c|}{ Concretes } \\
\hline & OPC & LF & GP & AFA \\
\hline Mass variation (\%) & -22.8 & -22.6 & -9.4 & -31.6 \\
\hline
\end{tabular}


2 Table 4. Atomic Fe/Cl ratio of corrosion products: empty cells signify that the associated corrosion 3 product is not observed in the concrete.

\begin{tabular}{|l|c|c|c|c|c|c|c|}
\cline { 2 - 8 } \multicolumn{1}{c|}{ Concretes } & $\begin{array}{l}\text { Nested } \\
\text { flower }\end{array}$ & Lamellar & Gel & $\begin{array}{l}\text { Hexagonal } \\
\text { crystal }\end{array}$ & Globular & Gel-globular & Nested needle \\
\hline OPC 0.55 & 2.1 & 1.8 & & & & & \\
\hline GP 0.55 & & & 12.3 & & & & \\
\hline AFA 0.55 & & & & 1.3 & & 2.2 & \\
\hline LF 0.55 & & 2.6 & 8.0 & & 2.7 & & 1.2 \\
\hline
\end{tabular}

4 


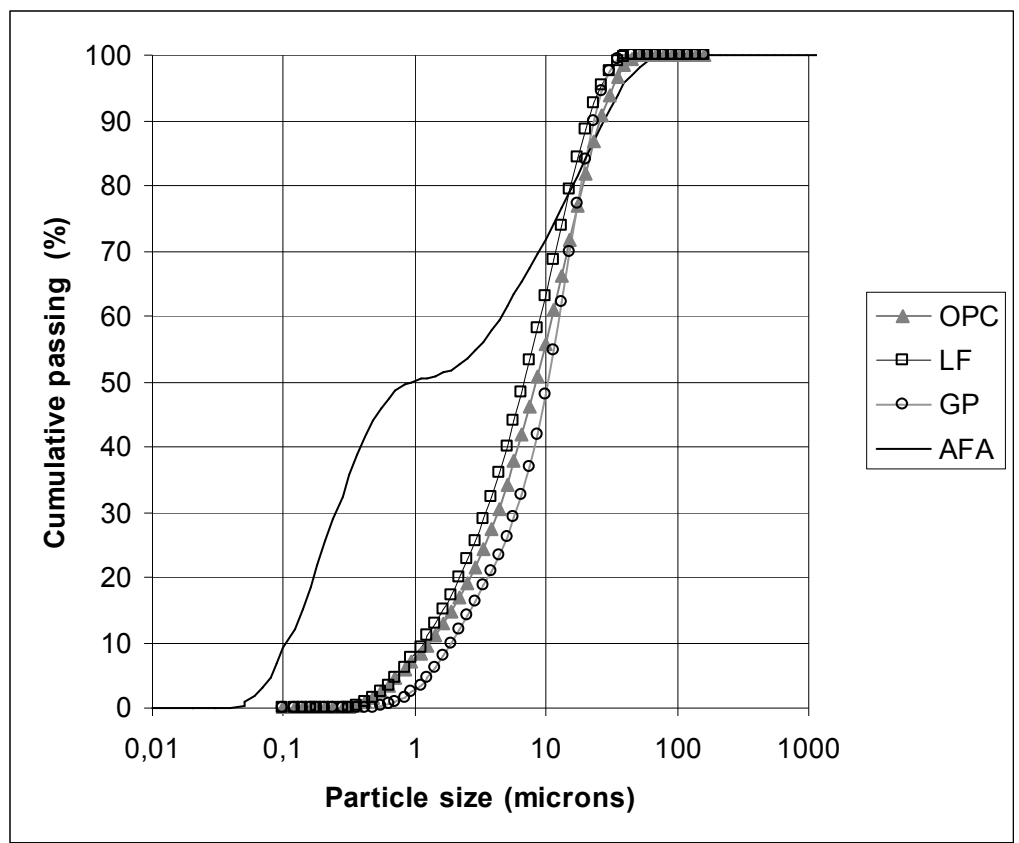

2

Figure 1 Particle size distribution of materials using laser granulometry.

3
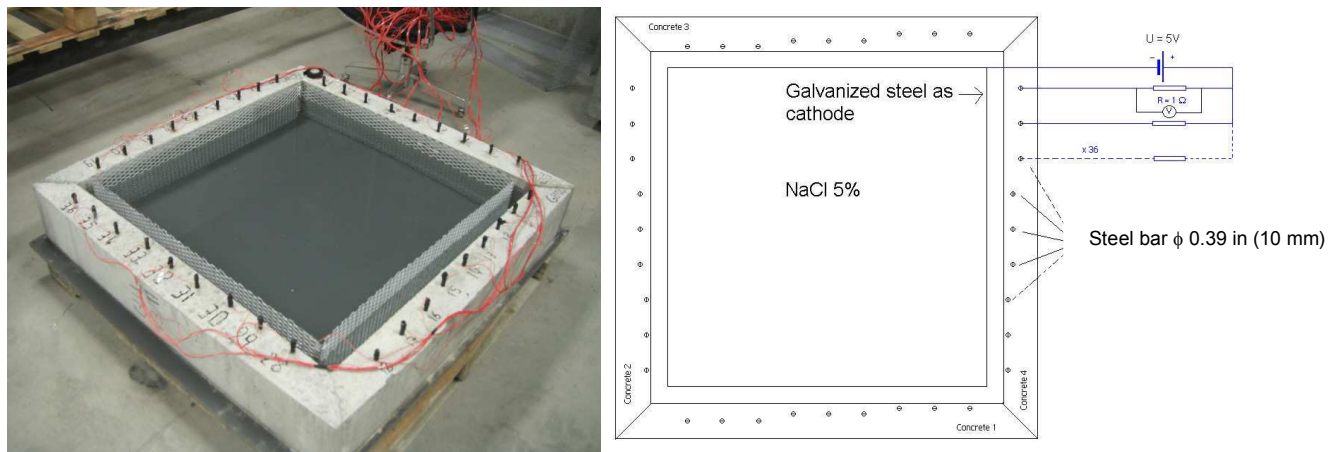

Figure 2 Experimental setup for accelerated corrosion test. 


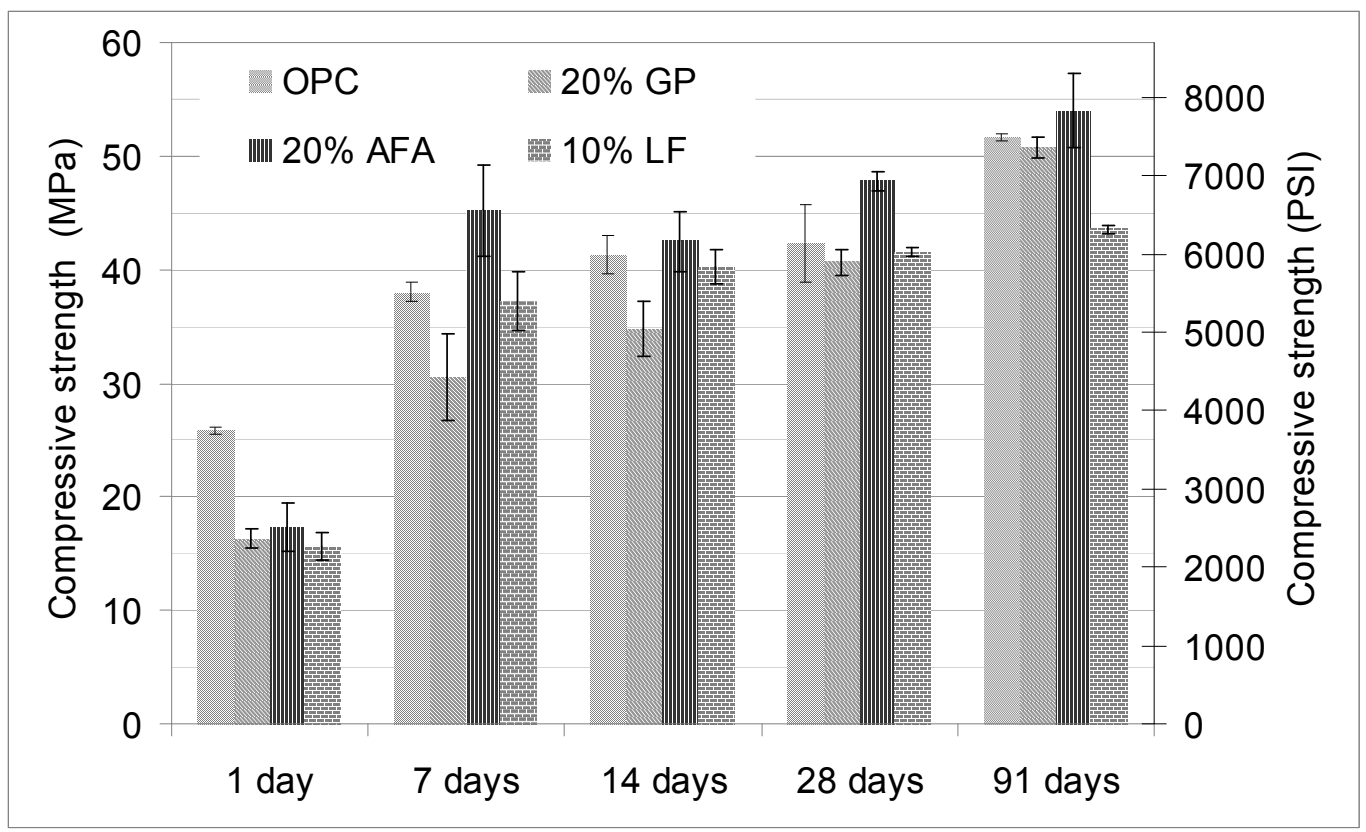

Figure 3 Compressive strength vs curing time for concretes with a W/B ratio of 0.4 .

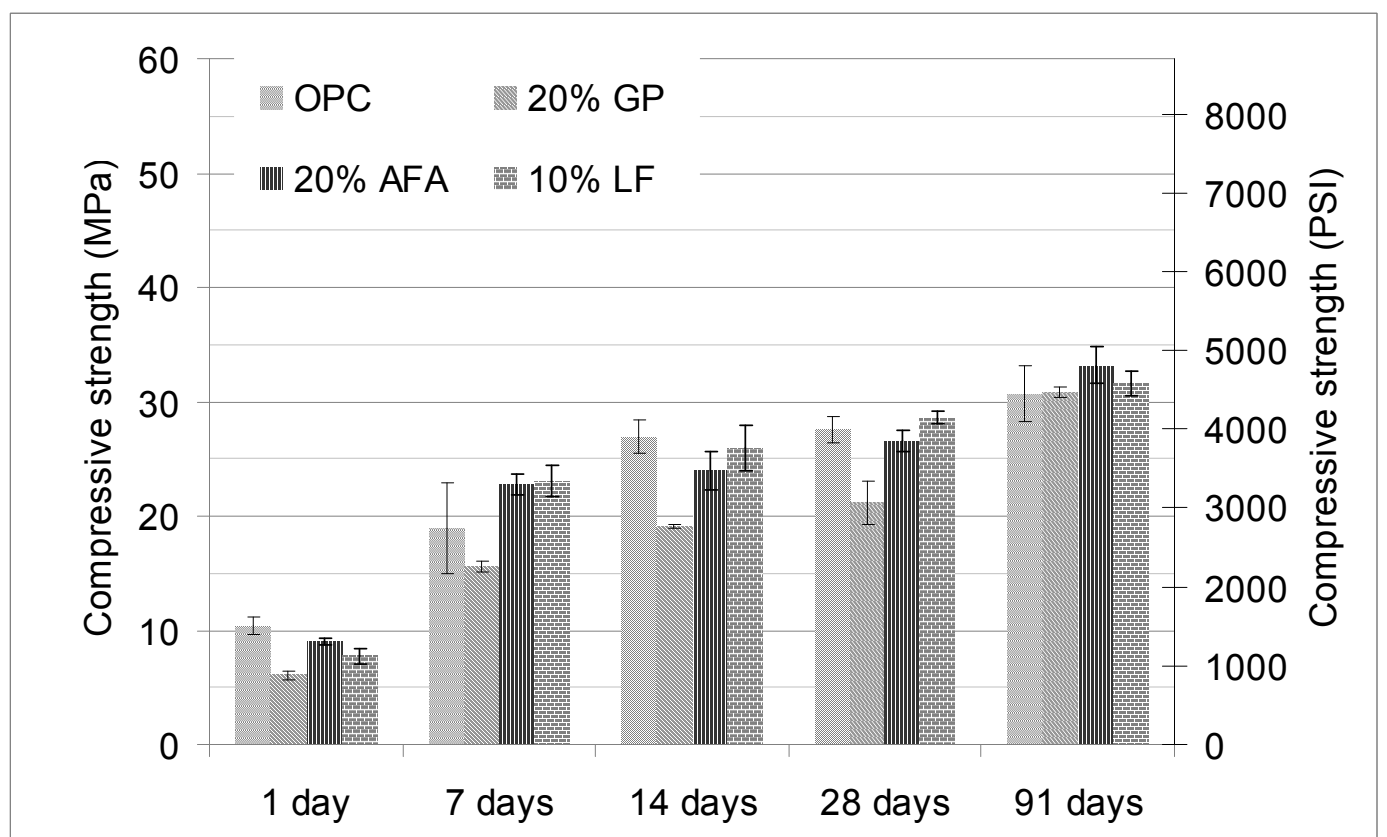

Figure 4 Compressive strength vs curing time for concretes with a W/B ratio of 0.55 . 


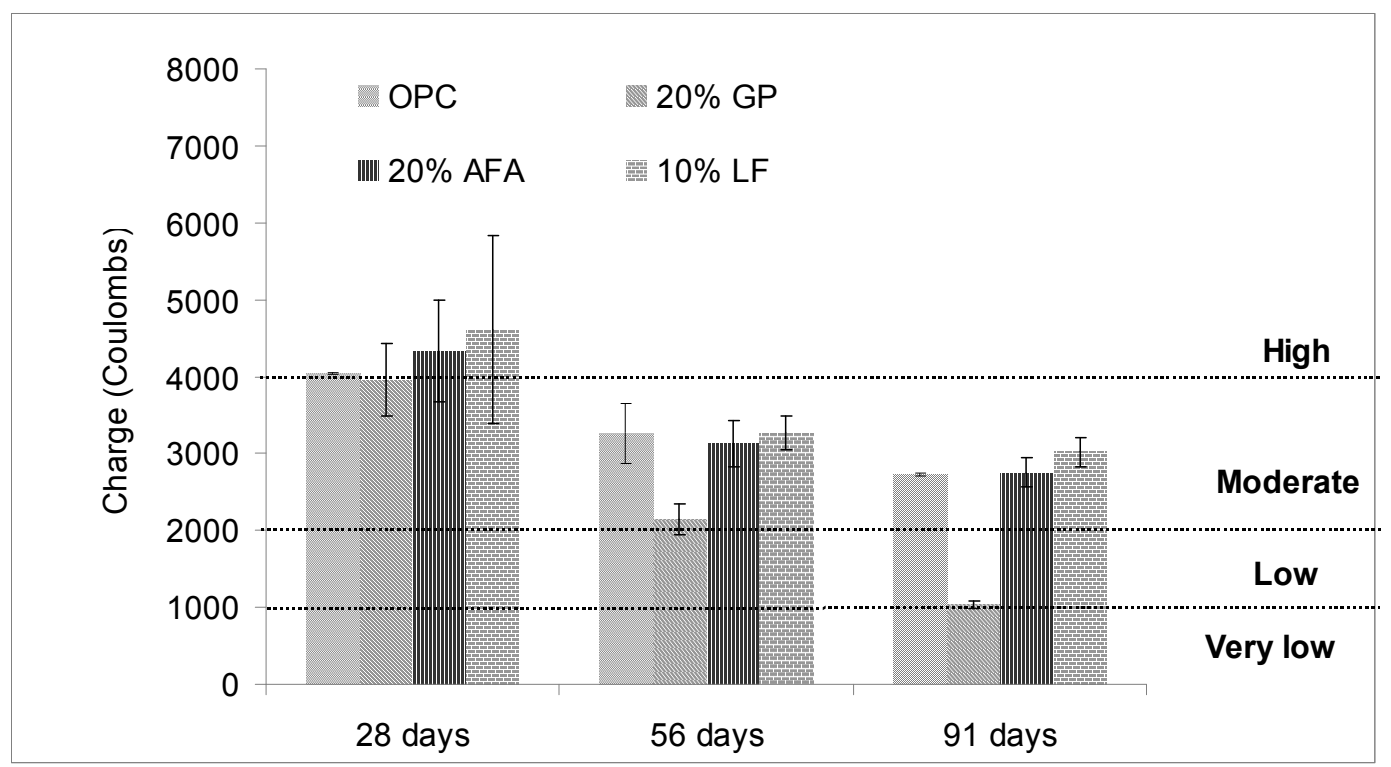

Figure 5 Chloride ion penetration of concretes with a W/B ratio of 0.4 vs curing time.

4

5

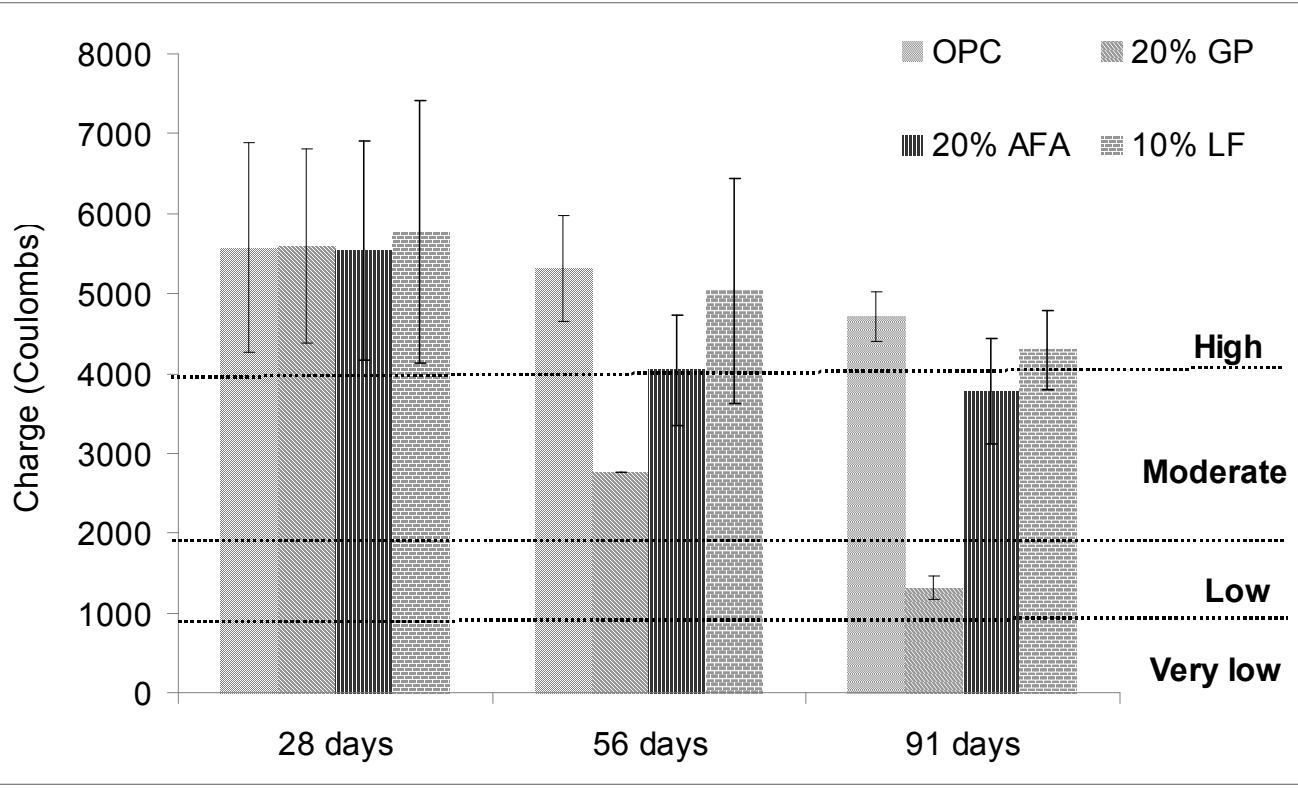

Figure 6 Chloride ion penetration of concretes with a W/B ratio of 0.55 vs curing time.

9 


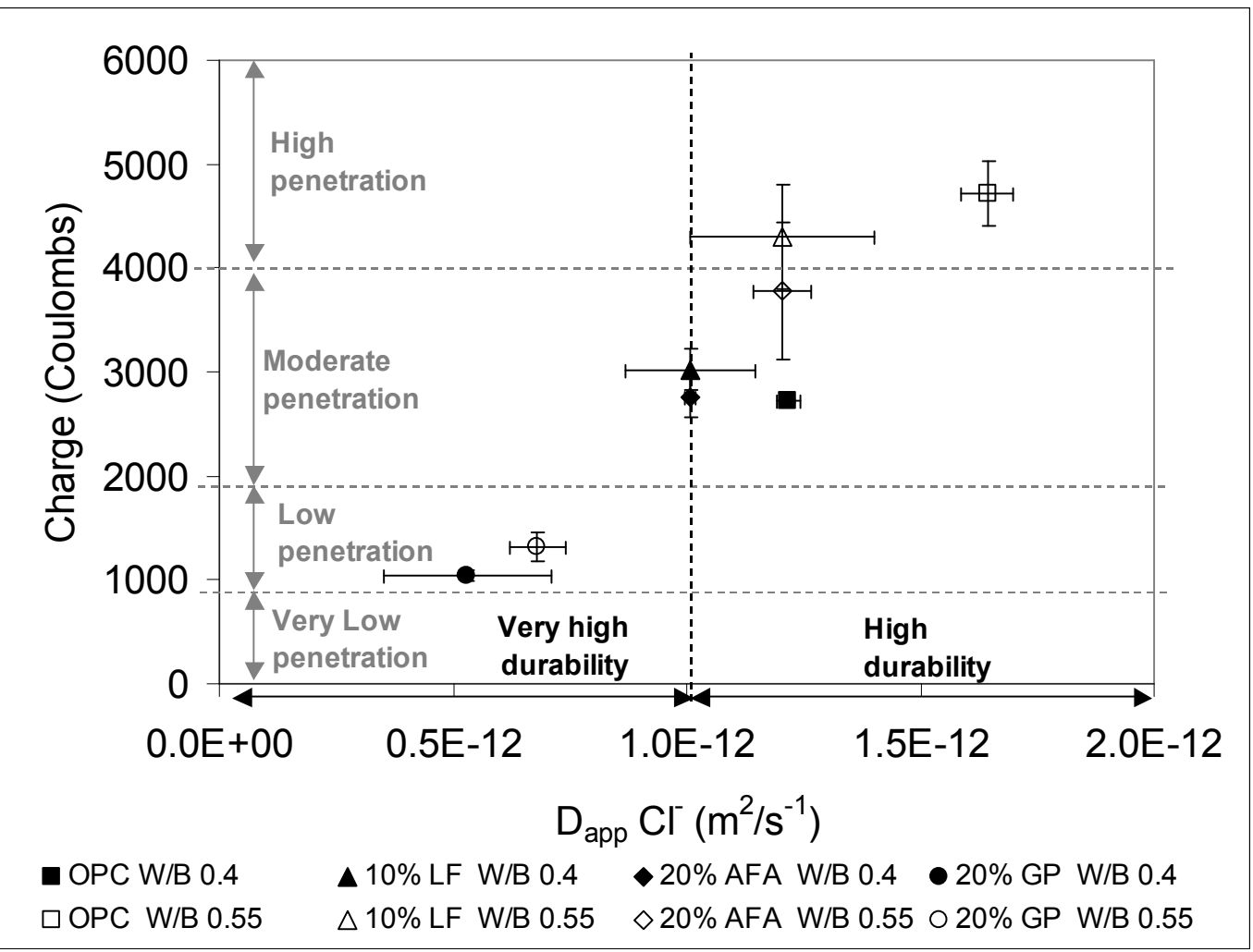

2 Figure 7 Comparison between chloride ion penetration obtained with ASTM C1202 ${ }^{27}$ and the coefficient 3 of apparent chloride ions diffusion obtained with the method recommended by AFGC ${ }^{28}$. 


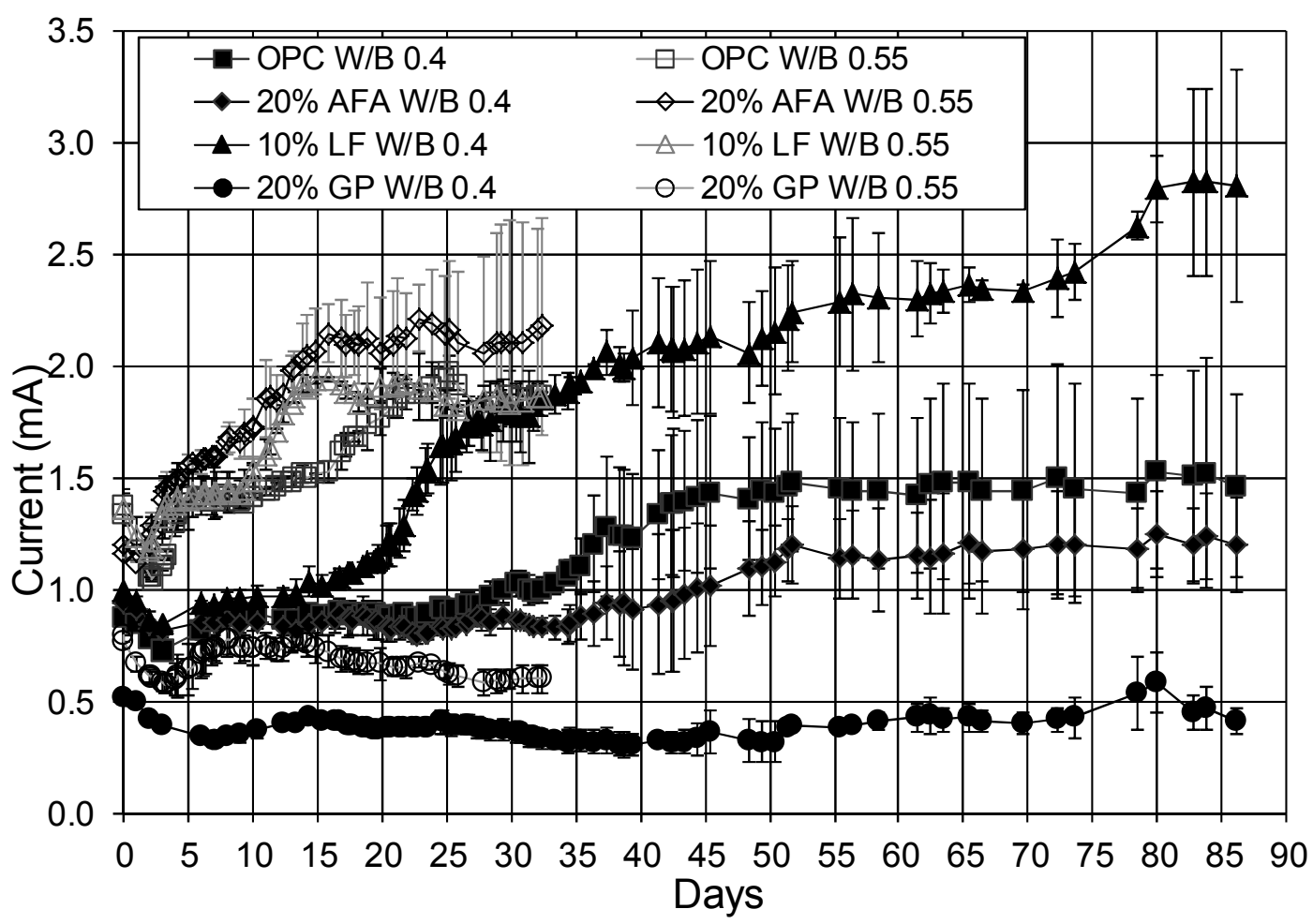

Figure 8 Corrosion accelerated test. Monitoring of electrical current in steel bars placed at 0.8 inch (20 $\mathrm{mm}$ ) from the saline solution.

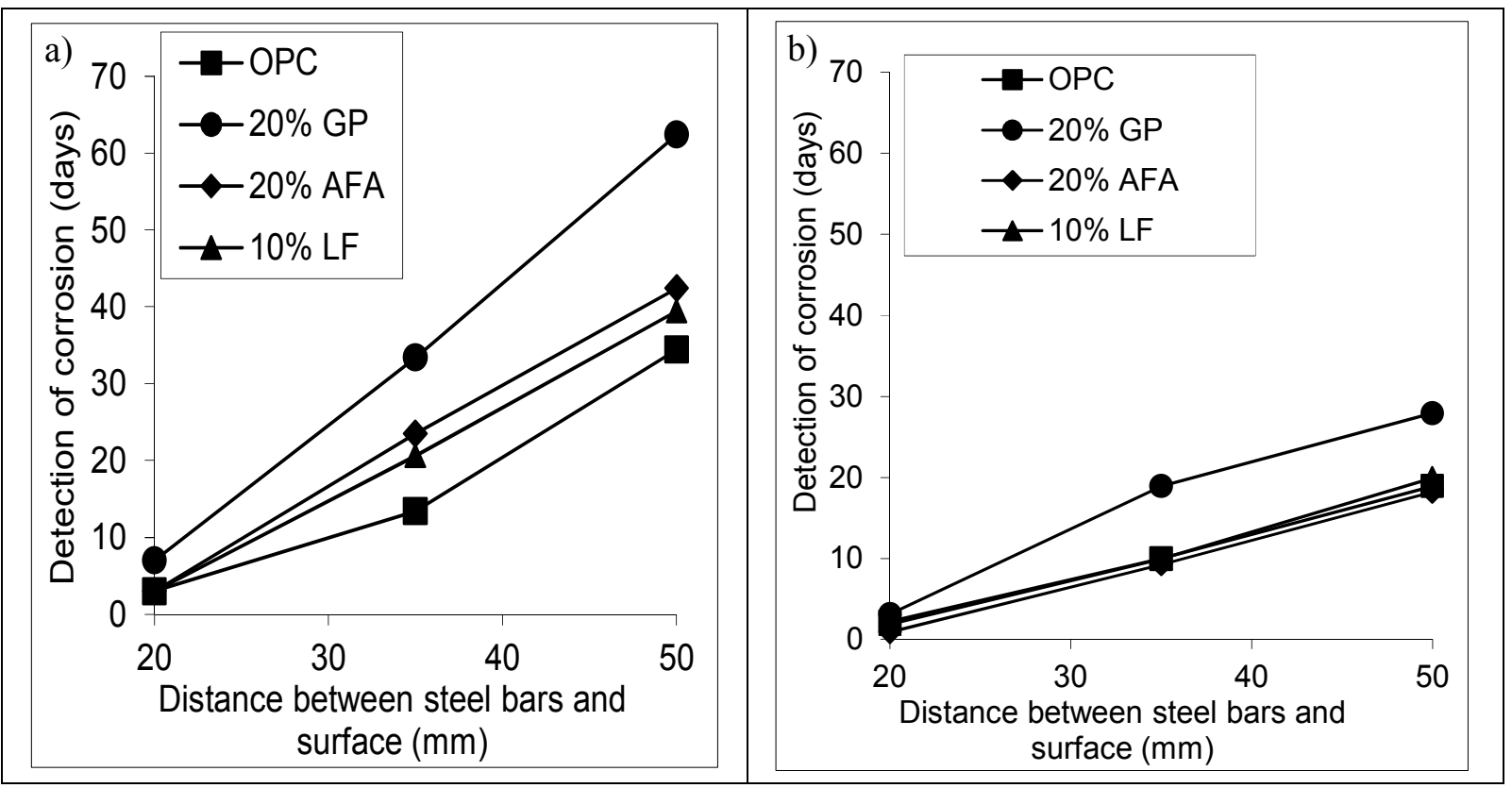

5

Figure 9. Time taken to detect of corrosion depending on the distance between steel bars and saline solution in concrete for W/B of 0.4 (a) and W/B of 0.55 (b) 


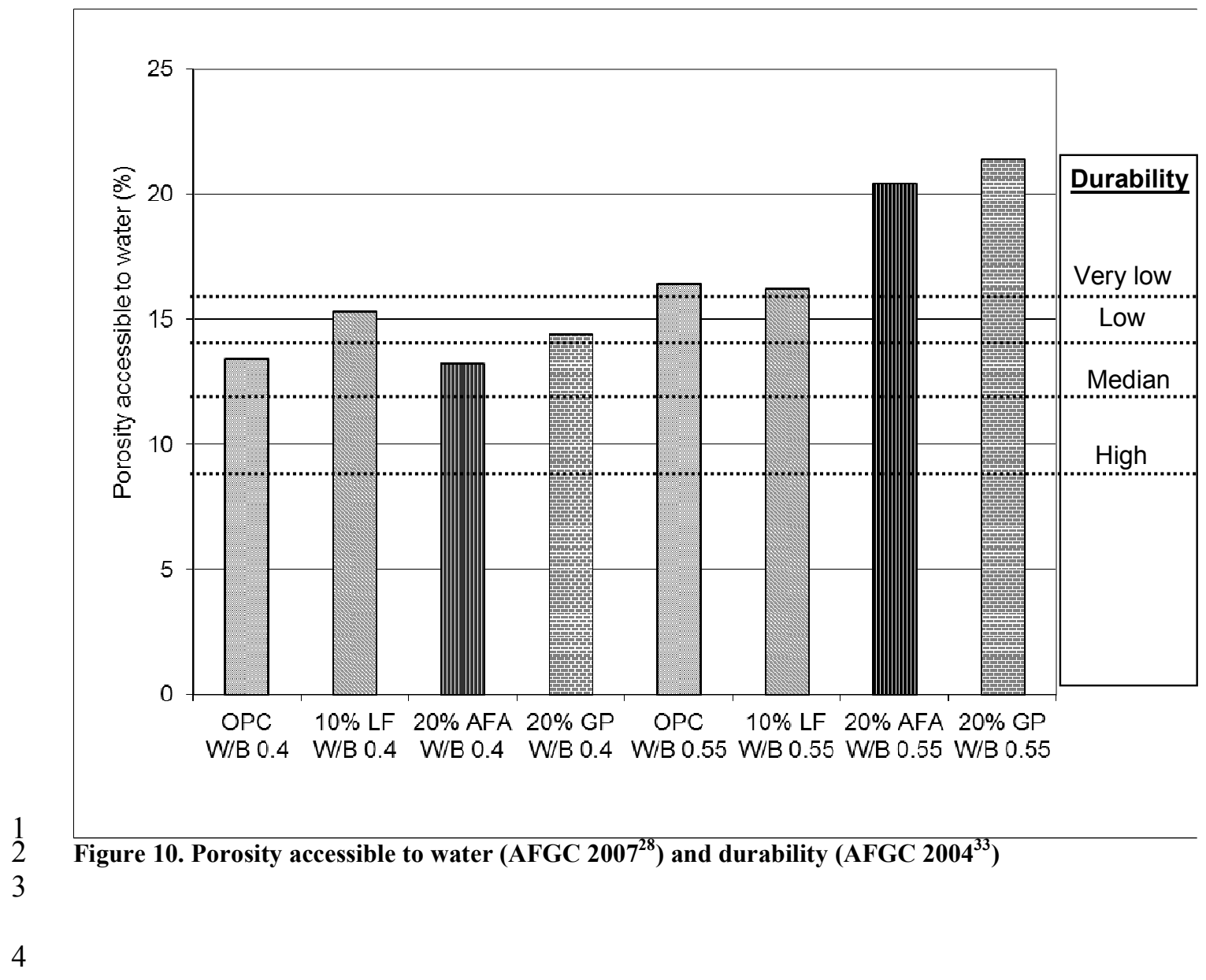



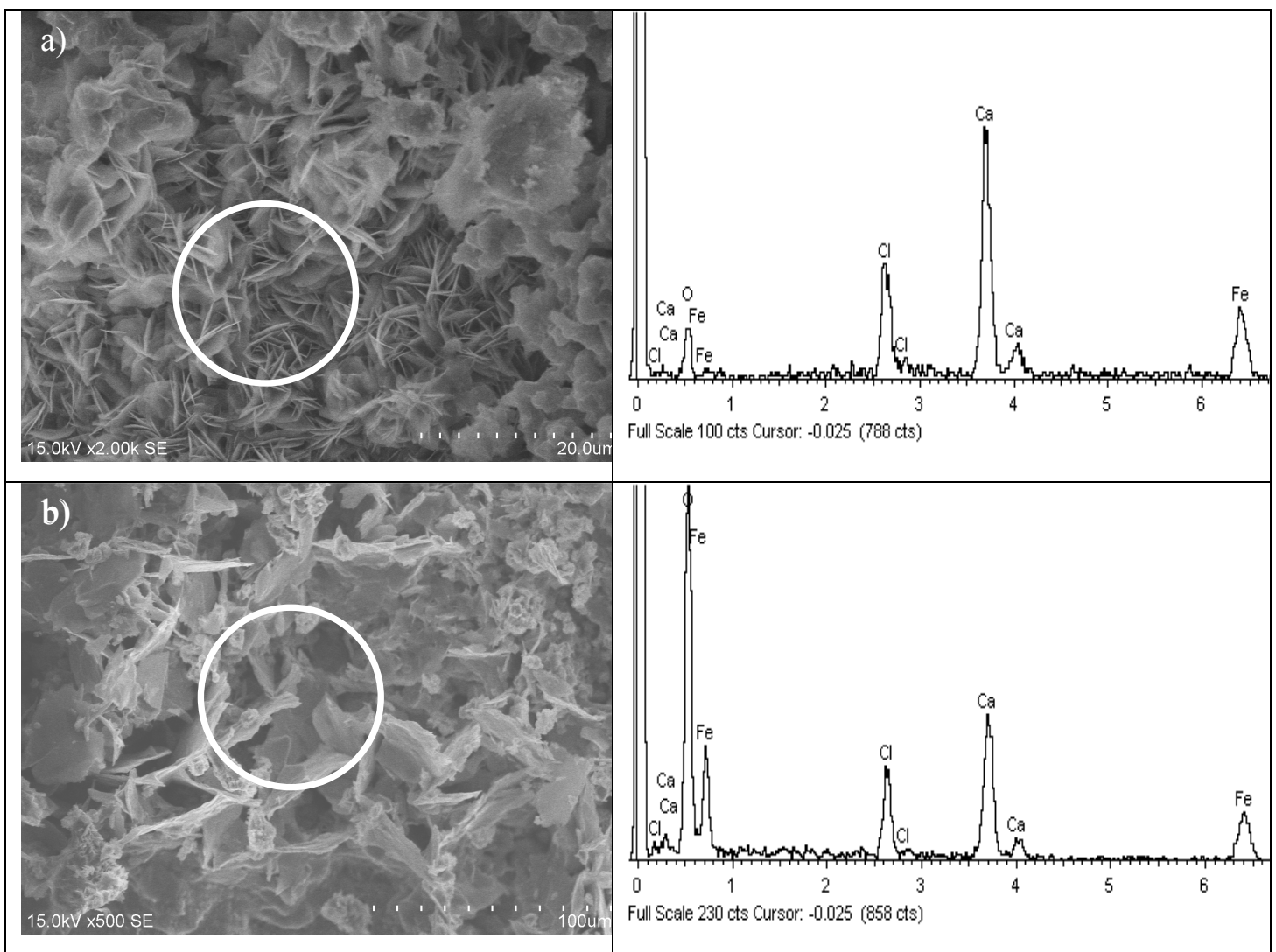

2 Figure 11. SEM micrographs and EDS spectra of a) nested flower-like and b) lamellar-like corrosion 3 products observed in OPC 0.55 .

4

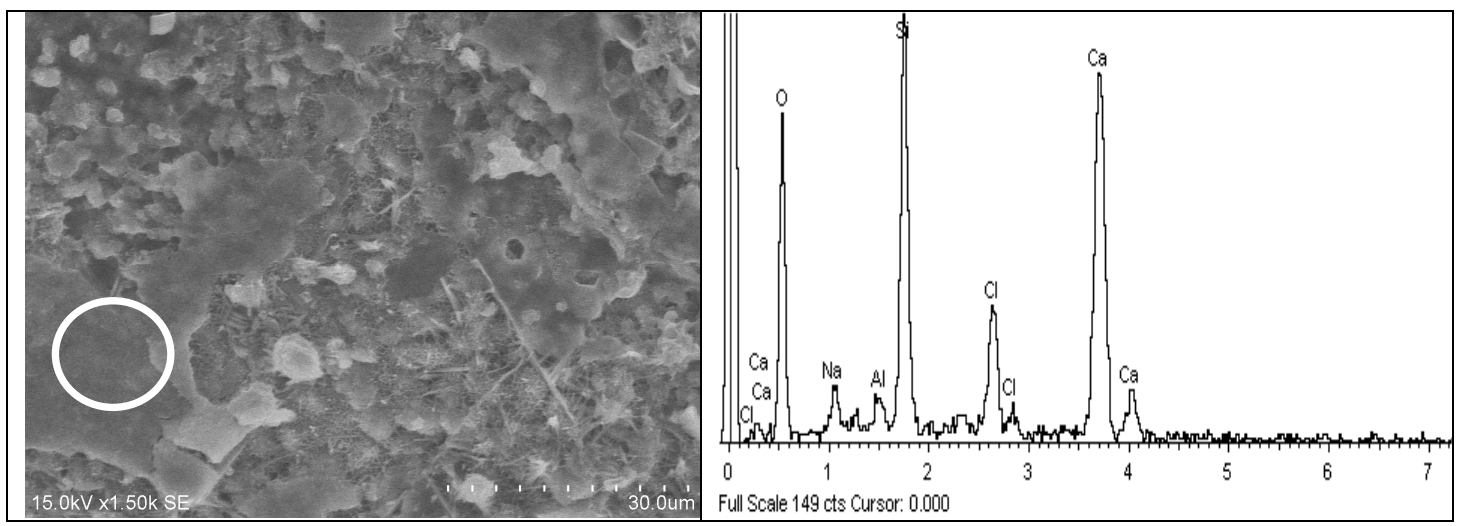

Figure 12. SEM micrographs and EDS spectra of gel-like corrosion product observed in GP 0.55. 6 


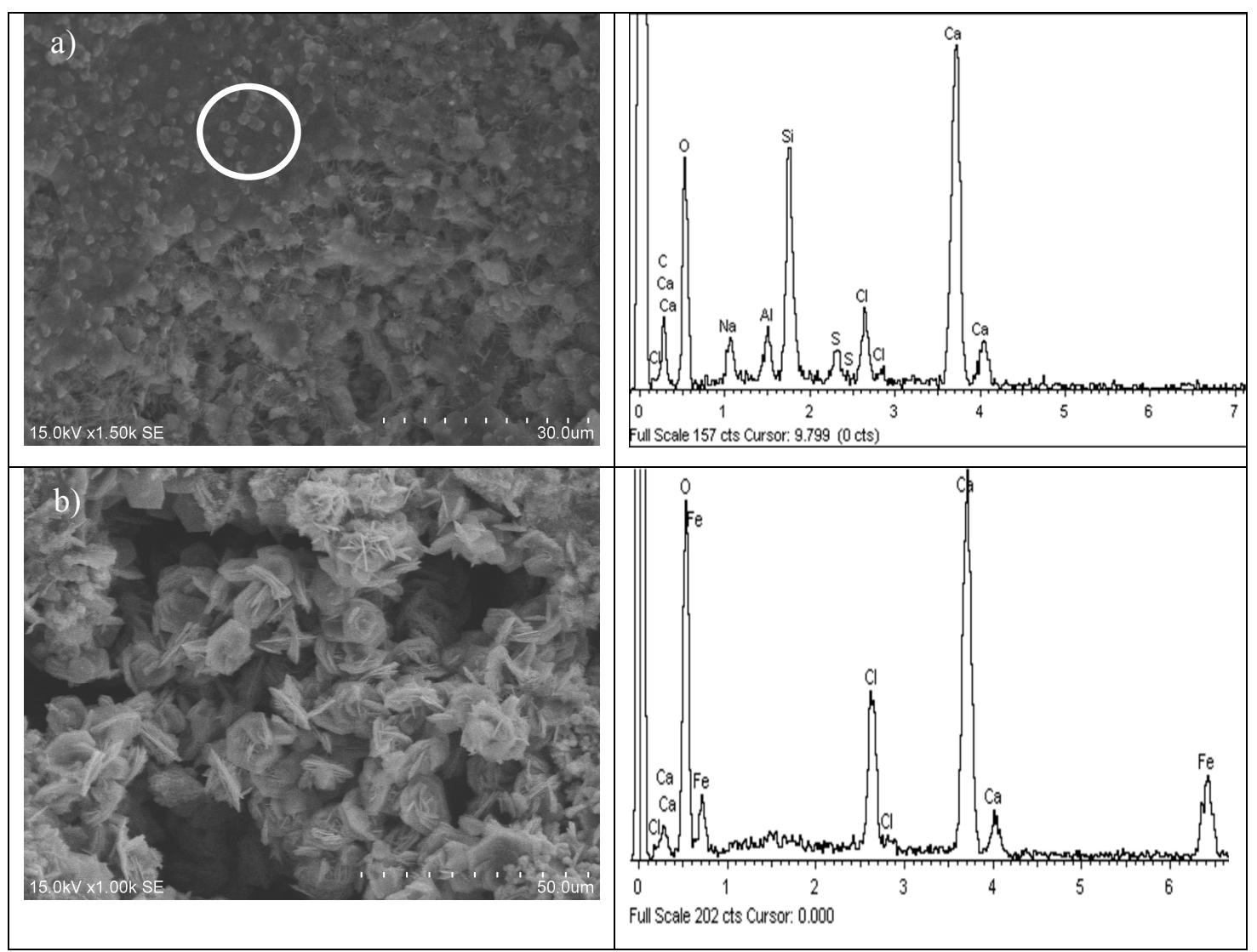

1 Figure 13. SEM micrographs and EDS spectra of a) gel-globular-like material and b) of hexagonal 2 crystal-like corrosion products in AFA 0.55. 

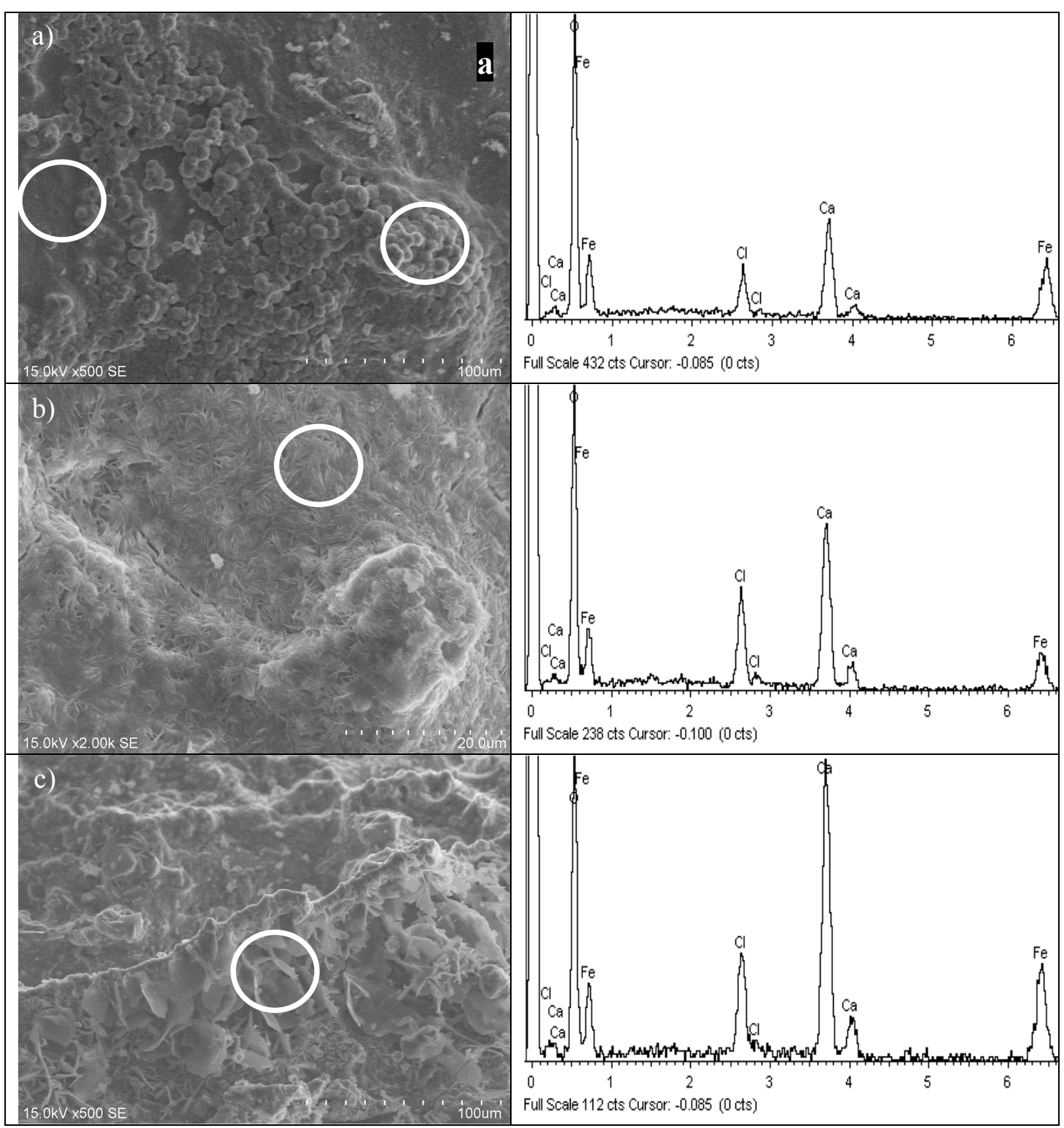

Figure 14. SEM micrographs and EDS spectra of a) gel-like and globular-like, b) nested needle-like and c) lamellar-like in LF 0.55 . 